\title{
Effects of scallop dredging on a soft sediment community: a large-scale experimental study
}

\author{
David R. Currie, Gregory D. Parry* \\ Victorian Fisheries Research Institute, PO Box 114, Queenschiff, Victoria 3225, Australia
}

\begin{abstract}
Changes to benthic infauna caused by scallop dredging at a site in Port Phillip Bay, southeastern Australia, were examined experimentally using a BACI (before, after, control, impact) design. The experimental dredging was undertaken by commercial fishermen and was typical of normal commercial operations in its spatial extent, intensity and duration. Changes to benthic community structure following dredging were monitored using grab samples taken on 3 occasions pre-dredging and 6 occasions post-dredging. The significance of changes was assessed using ANOVA for the more abundant species and, for pooled groups of species, Bray-Curtis community dissimilarities and multidimensional scaling (MDS). The abundance of 7 of the 10 most common species changed significantly (ANOVA p < $0.10)$ after dredging; 6 species decreased in abundance while 1 species increased. The size and persistence of dredging impacts varied between species, but most species decreased in abundance by 20 to $30 \%$. Dredging impacts became undetectable for most species following their next recruitment. Most species recruited within 6 mo of the dredging impact, but a small number of species still had not recruited after $14 \mathrm{mo}$. These latter species appeared to cause a persistent change in community structure which was still detectable after 14 mo using Bray-Curtis dissimilarities. MDS ordination indicated that changes to community structure caused by dredging were smaller than those that occur between seasons and years.
\end{abstract}

KEY WORDS: BACI - Benthic community - Environmental impact · Scallop dredging Fishing impact

\section{INTRODUCTION}

The impact of commercial fishing on the marine environment has been a matter of concern since at least the 14 th century (de Groot 1984). Different groups of fishermen have often raised this issue, particularly when they find themselves in competition (de Groot 1984, Jamieson \& Campbell 1985, Scarratt 1972, 1975 cited in Messieh et al. 1991). More recently the worldwide increase in environmental awareness has resulted in further concern as ever heavier fishing gear is towed by larger and more powerful vessels (Hall 1994). But few impacts of fishing have been well-documented and biological impacts are particularly difficult to investigate because of the complexity of benthic communities and our limited knowledge of its natural variability (Messieh et al. 1991, Gislason 1994).

•E-mail: g.parry@msl.oz.au
The impacts of trawls and dredges are often considered to be similar as both are towed across the surface sediments where they are likely to damage organisms near the surface. Several studies (Caddy 1973, de Groot 1984) have described changes to the topography of the sea bed caused by fishing gear, and these suggest that fishing gear penetrates 10 to $30 \mathrm{~mm}$ into the sediment depending upon the weight of the gear and the softness of the sediments (de Groot 1984). Typically, dredges (Caddy 1973) and to a lesser degree trawl nets (Krost et al. 1990) flatten existing topographic features while trawl doors dig 2 deep furrows up to $30 \mathrm{~cm}$ deep (Jones 1992). These topographic changes persist longer in deeper and more sheltered waters less exposed to wave action (de Groot 1984, Thiel \& Schriever 1990, Jones 1992).

Where trawls and dredges operate in areas with large amounts of epifauna or epiflora it is clear that they will dislodge or uproot much of this biota le.g. Hutchings 1990). Trawl nets typically catch much more 
bycatch than target species and most is returned to the sea dead (Andrew \& Pepperell 1992). Fragile epifauna such as razor shells, Tubularia beds, and Sabellaria reefs in the North Sea have been severely damaged by trawling (de Groot 1984). Sponge and bryozoan communities are also vulnerable to trawling, and changes caused to these communities result in changes to fish communities dependent on these habitats (Bradstock \& Gordon 1983, Sainsbury 1988). In contrast shellfish dredging often appears to occur in localities where the target species is the dominant species of epibiota (e.g. Caddy 1973, Butcher et al. 1981), so the proportion of non-target species in the catch is low. But where shellfish dredging occurs at sites with significant amounts of epibiota most will be removed. Dredging reduces seagrass abundance and may cause seagrass habitats to be replaced by unvegetated sand flats (Peterson et al. 1987). Few indirect effects of dredging and trawling have been documented but benthic animals exposed or damaged by fishing attract predators (Arntz \& Weber 1970, Caddy 1973), and where large amounts of bycatch are discarded scavenger populations may increase (e.g. Wassenberg \& Hill 1990, Britton \& Morton 1994).

Unfortunately previous studies of impacts of commercial trawling and dredging are either qualitative (Caddy 1973, Butcher et al. 1981) or involve the disturbance of such small experimental areas (e.g. McShane 1981, Eleftheriou \& Robertson 1992) that extrapolating the results to the scale of the commercial fishery is uncertain. Even the largest controlled experimental study of impacts due to shellfish dredging (Peterson et al. 1987) involved simulated dredging ('kicking') of 12 experimental plots only $1225 \mathrm{~m}^{2}$. In this experimental study changes were measured on a $360000 \mathrm{~m}^{2}$ plot subject to supervised dredging by commercial scallop vessels. Thus we measured changes to the benthic community caused by dredging on a scale directly relevant to the impact of a commercial fishery.

The expense of sorting and identifying benthic animals has both limited the number of experimental studies of the impact of fishing, and necessitated some compromises in their design. Control sites have often not been sampled (McShane 1981, Bergman \& Hup 1992) and sampling intensities are usually low so that only a large impact would be detected (e.g. McShane 1981, Peterson et al. 1987, Eleftheriou \& Robertson 1992). In this study much smaller changes were detectable, as the total number of organisms identified in this study (>100000 individuals) was an order of magnitude greater than in previous studies. Even small changes measured at an experimental site may be important if they lead to changes throughout an extensive fished area, especially since tests of low power could lead to an incorrect conclusion of no impact.
The scallop industry in Port Phillip Bay is a valuable commercial fishery in southeastern Australia and has produced up to $2000 \mathrm{t}$, worth approximately $\$ 20$ million, annually. Dredging for scallops Pecten fumatus in Port Phillip Bay is also widely regarded by the local community as environmentally damaging. Many changes to the ecology of Port Phillip Bay noted by fishermen and others have been attributed (rightly or wrongly) to scallop dredging. In response to these concerns, a series of linked biological and physical studies were initiated in 1991 to provide information on the extent of impacts due to scallop dredging. Experimental studies were undertaken in 3 large areas (30 to $40 \mathrm{~km}^{2}$ ) of Port Phillip Bay (Fig. 1) which was closed to all scallop dredging throughout 1991 (see Parry \& Currie 1992). Dredging-related changes to the abundance and diversity of benthic animals were examined using a BACI (before, after, control, impact) experimental design (see Stewart-Oaten et al. 1986). This design involves simultaneous sampling of 2 plots ( 1 'control' and 1 'dredge') on a number of occasions, both before and after experimentally dredging 1 plot. The magnitude and duration of changes to the soft bottom community near St. Leonards (Fig. 1) are described. The expense of this large-scale experiment (see Warwick 1993) meant that at the other 2 study areas, Dromana and Portarlington (Fig. 1), only short-term changes to benthic communities following dredging could be monitored (Currie \& Parry unpubl.). The effects of changes to benthic communities on fish communities following dredging were monitored for several months at St. Leonards and for shorter periods at Dromana and Portarlington (Parry \& Currie unpubl.). At all 3 areas the effect of dredging on turbidity and sedimentation rates were also monitored (Black \& Parry 1994).

\section{METHODS}

Study area. The Port Phillip Bay scallop fishery commenced in 1963, and catches and dredging intensity increased dramatically until the fishery collapsed in 1968 (Gwyther \& McShane 1988). The total number of hours dredging is now much lower than in the early years of the fishery (Currie \& Parry unpubl.), but there are still 84 vessels licensed to dredge for scallops in Port Phillip Bay. Since 1963 all but the shallowest regions of the Bay have been dredged, but with varying intensities. Most scallop dredging occurs in depths between 10 and $20 \mathrm{~m}$, and since 1985 dredging has been illegal in areas shallower than $10 \mathrm{~m}$ in the east and shallower than $5 \mathrm{~m}$ in the west of the Bay.

The intensity with which different areas of Port Phillip Bay have been dredged historically was calcu- 

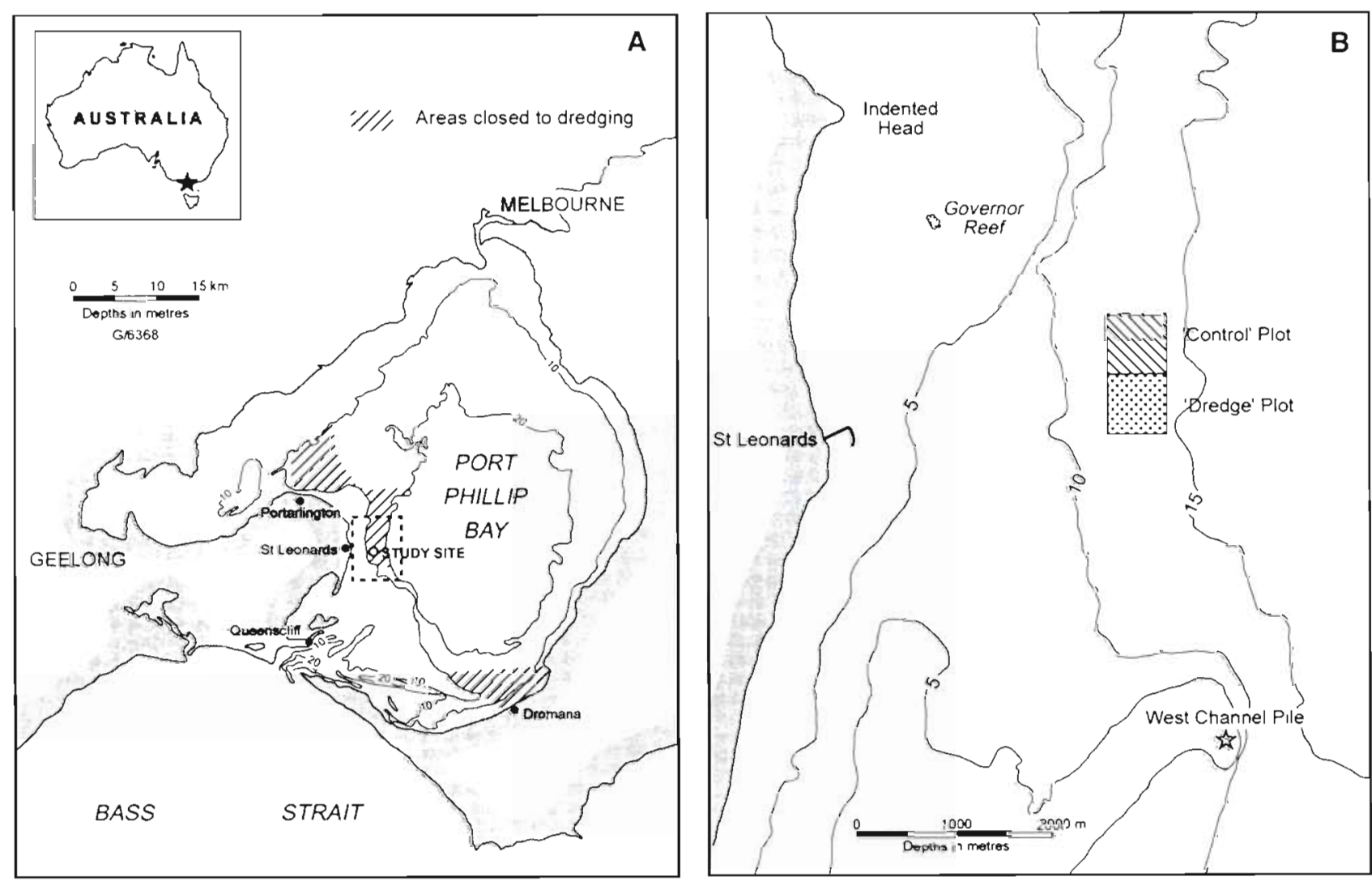

Fig. 1. (A) Location of study site. Hatched areas were closed to all but experimental scallop dredging during this study. Rectangle is fishing sector 43 . (B) Location of study plots

lated to determine the appropriate intensity of experimental dredging to use in our study. For the period 1980 to 1990 the annual number of hours fished in each of 70 reporting sectors (each 2 to $44 \mathrm{~km}^{2}$ in area) was estimated from fishing effort information (hours fished per month per fisherman) provided by fishermen and summarised in the Victorian Fisheries Catch and Effort Database (Australia). The annual intensity of dredging in each sector was estimated from the total fishing time in the sector, the total area deeper than 5 or $10 \mathrm{~m}$ that could be dredged legally in the sector, the proportion of fishing time that involved dredging on the sea floor (40 min dredging in 60 min fishing, Gwyther \& Parry pers. obs.), the average vessel speed ( 5 knots) and the dredge width $(3.0 \mathrm{~m})$. Within each sector the undredged area, the area passed over once by a dredge $(1 \times$, dredging intensity), the area passed over twice by a dredge $(2 \times$, dredging intensity), etc. was estimated using a Poisson distribution:

$$
\operatorname{Area}(n)=A \times \mathrm{e}^{-1} \times I^{n} / n !
$$

where Area $(n)$ is the area passed over $n$ times by a dredge, $A$ is the area of the sector, and $I$ is the average intensity with which the sector is dredged.
Estimates for each sector were summed to estimate the total area of Port Phillip Bay dredged with each intensity (Table $1 \mathrm{~A}$ ). These estimates are only approximate and will overestimate the area dredged with low intensity and underestimate the area dredged with high intensity where dredging is concentrated in only part of a sector. The historical intensity of dredging in Sector 43, which included the St. Leonards study area (Fig. 1A), is shown in Table 1B.

Study design and statistical analysis. Typically, commercial scallop vessels in Port Phillip Bay work close together in groups of 5 to 50 vessels. Within each group dredges are dragged in the same direction for 500 to $2000 \mathrm{~m}$ before they are emptied and dragged in the opposite direction. Fishermen usually target a region until the catch rate there becomes low and they do not usually return to the same region until the following year. The experimental study was designed to closely duplicate normal fishing practice. A single large plot was dredged because this created an impact similar in scale to that caused by commercial scallop fishermen over a 2 to $3 \mathrm{~d}$ period. The large size of the plots also enabled changes to fish populations within the plots to be monitored using a large trawl net (Parry \& Currie 
Table 1. Percentage of total area dredged with different intensities between 1980 and 1990 in: (A) Port Phillip Bay (area $1920 \mathrm{~km}^{2}$ ), which was used to determine appropriate intensity for experimental dredging; and (B) St. Leonards, Sector 43 (Fig. 1. area $44.1 \mathrm{~km}^{2}$ ) which documents the historical intensity of dredging in the study area. Dredging intensity is the number of times an area is traversed by a dredge: $\times 1=$ area traversed once by dredge, $\times 2=$ area traversed twice by dredge, etc.

\begin{tabular}{|c|c|c|c|c|c|c|c|c|c|c|c|c|c|}
\hline $\begin{array}{l}\text { Dredging } \\
\text { intensity }\end{array}$ & 1980 & 1981 & 1982 & 1983 & 1984 & 1985 & 1986 & 1987 & 1988 & 1989 & 1990 & \multicolumn{2}{|c|}{$\begin{array}{c}\text { Average } 1980-1990 \\
\quad\left(\text { area } \mathrm{km}^{2}\right)\end{array}$} \\
\hline \multicolumn{14}{|c|}{ (A) Port Phillip Bay } \\
\hline \multirow{2}{*}{$\begin{array}{l}\text { Undredged } \\
\times 1\end{array}$} & 80.4 & 81.9 & 71.9 & 80.5 & 81.3 & 78.6 & 89.3 & 82.4 & 99.8 & \multirow[t]{5}{*}{100} & \multirow[t]{5}{*}{100} & 86.0 & \\
\hline & 14.3 & 12.0 & 18.0 & 14.5 & 13.4 & 14.7 & 9.0 & 12.7 & 0.2 & & & 9.9 & $(190)$ \\
\hline$\times 2$ & 3.6 & 3.5 & 6.6 & 3.8 & 3.7 & 4.0 & 1.4 & 3.4 & & & & 2.7 & (52) \\
\hline$\times 3$ & 1.1 & 1.4 & 2.3 & 0.9 & 1.0 & 1.5 & 0.2 & 1.0 & & & & 0.9 & (17) \\
\hline$>\times 3$ & 0.5 & 1.1 & 1.2 & 0.3 & 0.4 & 1.2 & & 0.5 & & & & 0.5 & (10) \\
\hline Total dredged & 19.6 & 18.1 & 28.1 & 19.5 & 18.7 & 21.4 & 10.7 & 17.6 & 0.2 & 0.0 & 0.0 & 14.0 & (269) \\
\hline \multicolumn{14}{|c|}{ (B) St. Leonards, Sector 43} \\
\hline Undredged & 85.5 & 90.6 & 83.9 & 84.6 & 90.6 & 80.7 & 85.0 & 75.9 & 99.8 & 100 & 100 & \multicolumn{2}{|l|}{88.8} \\
\hline$\times 1$ & 13.4 & 9.0 & 14.8 & 14.2 & 8.9 & 17.3 & 138 & 20.9 & 0.2 & & & \multicolumn{2}{|l|}{10.2} \\
\hline$\times 2$ & 1.1 & 0.4 & 1.3 & 1.2 & 0.4 & 1.9 & 1.1 & 2.9 & & & & \multicolumn{2}{|l|}{0.9} \\
\hline$\times 3$ & 0.1 & & 0.1 & 0.1 & & 0.1 & 0.1 & 0.3 & & & & \multicolumn{2}{|l|}{0.1} \\
\hline \multicolumn{14}{|l|}{$>\times 3$} \\
\hline Total dredged & 14.5 & 9.4 & 16.1 & 15.4 & 9.4 & 19.3 & 15.0 & 24.1 & 0.2 & 0.0 & 0.0 & \multicolumn{2}{|l|}{11.2} \\
\hline
\end{tabular}

unpubl.). However, their large sizes made replication of the control plot prohibitively expensive and limited replication of the dredge plots to uncontrolled beforeafter comparisons at the other experimental sites (Currie \& Parry unpubl.). These pragmatic considerations meant that there was only limited spatial replication (Hurlbert 1987, Underwood 1991)

Two adjacent $600 \times 600 \mathrm{~m}$ experimental plots were located in 12 to $15 \mathrm{~m}$ of water, approximately $2 \mathrm{~km}$ offshore from St. Leonards. The southern plot was experimentally dredged by commercial vessels ('dredge' plot) and the northern plot was left undredged ('control' plot) (Fig. 1B). The dredge plot was dredged over $3 \mathrm{~d}$ (16 to 18 July 1991) by a fleet of 6 commercial scallop vessels, using $3 \mathrm{~m}$ wide 'Peninsula' dredges fitted with scraper/cutter bars that did not extend below the level of the skids (see diagram in Hughes 1973). Dredging was conducted for a maximum of only $3 \mathrm{~h} \mathrm{~d}^{-1}$ and coincided with periods in which there was a strong southerly tidal current that carried dredging-related sediment away from the adjacent control site. Dredging was continued until the entire plot had, on average, been passed over twice by a scallop dredge. This intensity of dredging ( $2 x_{\text {; }}$ Table 1A) was consistent with a moderately high fishing intensity based on historical levels in Port Phillip Bay. During the 1980s an average of $52 \mathrm{~km}^{2}$ of Port Phillip Bay was dredged with this intensity annually, and the maximum area dredged with this intensity was $127 \mathrm{~km}^{2}$ in 1982 (Table 1A). A lower level of dredging would also have made detection of impacts more difficult as much of the 'dredged' plot would have remained undredged. At the $2 \times$ dredging intensity used in this experiment it was estimated, using Eq. (1), that $13 \%$ of the plot remained undredged.

On the first morning of the experimental dredging the plot to be dredged was marked with 4 equidistant buoys along each side of the $600 \times 600 \mathrm{~m}$ plot using a Furuno GP 500 GPS Navigator connected to a colour video plotter. This GPS provides an accuracy of 15 to $25 \mathrm{~m}$ in $95 \%$ of fixes. Where inaccuracy exceeded $25 \mathrm{~m}$ due to intentional degradation of the system (selective availability) this was obvious on the plotter. The buoys marked out three $200 \times 600 \mathrm{~m}$ lanes directed east-west. Scallop vessels dredged these lanes sequentially and fishermen were encouraged to dredge the whole area as evenily as possible. On the second and third days of dredging the buoys marking the lane boundaries were moved $50 \mathrm{~m}$ north and south of their initial positions to minimise any undredged 'shadows' resulting from vessels not dredging near buoys.

To assess visually apparent changes caused by dredging, diver-operated video recordings were taken of the sea bed on both plots 3 mo before dredging (11 April 1991), 8 d after dredging (25 July 1991), 6 mo after dredging (23 January 1992) and 11 mo after dredging (19 June 1992).

The depth of bed sediment disturbed by dredges was determined using 32 sets of colour-coded 'depth rings', which were inserted $20,40,60$ and $80 \mathrm{~mm}$ into the sediment within the dredge plot before dredging commenced. During the experimental dredging observers on each vessel identified each ring and therefore were able to determine the depth from which it was collected (Black \& Parry 1994) 
The vertical distribution of the fauna in the sediment was sampled on the control plot on 11 April 1994 by divers using four $120 \mathrm{~mm}$ diameter cores. Cores were taken haphazardly within a $50 \times 50 \mathrm{~m}$ area and separated into 3 strata: surface to $5 \mathrm{~cm}, 5$ to $10 \mathrm{~cm}$, and 10 to $20 \mathrm{~cm}$, and the number of animals in each stratum was counted.

To determine the abundance and size of callianassid mounds, divers counted and measured the height of all mounds in two $50 \times 1 \mathrm{~m}$ transects on the control plot on 16 August 1992. A ruler was inserted into each mound to determine its height.

To determine how selectively benthic organisms were dislodged from the sediment by dredging, a specially designed 'plankton' net (1 mm mesh, $300 \mathrm{~mm}$ mouth diameter, $900 \mathrm{~mm}$ length) was attached to the upper rear section of a scallop dredge to sample animals thrown up in the sediment plume during the experimental dredging. A net sample was collected approximately every 10 th drag for the first $2 \mathrm{~d}$ of dredging. The 5 net samples collected were subdivided using a plankton splitter and all organisms in $1 / 16$ to $1 / 4$ of a sample were identified and counted. For the 30 most common species differences between their relative abundance in the net and their relative abundance in the benthos immediately before dredging (2 July 1991) were tested using a $\chi^{2}$ test. The significance of progressive changes in species composition in the net during the dredging was determined for the 10 most common species from regressions of relative abundance versus time from the commencement of dredging (see Fig. 3)

The distribution and abundance of infauna at each plot were determined from replicate $0.1 \mathrm{~m}^{2}$ SmithMcIntyre grab samples. Fifteen samples were taken from each plot on 3 sampling dates before and 6 after the experimental dredging (i.e. a total of 270 grabs). Samples were taken 3 mo before dredging (8 April 1991), 2 mo before dredging (13 May 1991), 2 wk before dredging (2 July 1991), immediately after dredging (18 July 1991), 3 wk after dredging (9 August 1991), 3.5 mo after dredging (31 October 1991), 5 mo after dredging (16 December 1991), 8 mo after dredging (25 March 1992), and 14 mo after dredging (23 September 1992). Plots were sampled using a mixture of stratified random and random sampling. Each plot was subdivided into 12 equal sectors and one grab was taken at random from within each sector and the remaining 3 grab samples were taken at random across the plot. Samples were drained, weighed and a $70 \mathrm{ml}$ subsample retained for sediment analysis. All animals retained on a $1.0 \mathrm{~mm}$ sieve were sorted to the lowest practical taxonomic level (generally species) under a dissecting microscope before being counted
Changes to benthic communities following dredging were assessed using Bray-Curtis (B-C) dissimilarity measures (Bray \& Curtis 1957) and multidimensional scaling (MDS). Analysis of variance (ANOVA) was used to determine the significance of changes to the more common species following dredging. ANOVA was also used to determine whether there were any common features to species which were impacted by dredging. The significance of changes to the abundance of species groupings based on their taxonomic affinity, feeding type, depth of occurrence in the substrate, and rarity were all tested. The percentage change experienced by different species and species groupings following dredging was also documented to determine the extent to which they were impacted by dredging.

Differences between the control and dredge plots on each sampling date were examined using B-C dissimilarity measures. This measure was chosen because it is not affected by joint absences, it gives more weighting to abundant than rare species, and it has consistently performed well in preserving 'ecological distance' in a variety of simulations on different types of data (Field et al. 1982, Faith et al. 1987). For each sampling date, data from the 15 replicate grabs on each plot were pooled giving the total number of individuals found on that plot. Before calculating the B-C dissimilarity measures, square root, double square root, and presence/ absence transformations were applied to the number of individuals of each species. These progressively more severe transformations prevent abundant species from influencing the B-C dissimilarity excessively (e.g. Clarke \& Green 1988, Clarke 1993). For each transformation, 9 pairwise B-C dissimilarity measures comprising all control plot versus dredge plot comparisons for the 9 sampling dates ( 3 pre-dredging and 6 postdredging) were used in the BACl analysis as proposed by Faith et al. (1991). To estimate the duration of the impact, $t$-tests were calculated using all pre-dredging dissimilarity measures and with progressively $3,4,5$, and 6 post-dredging dissimilarity measures.

Temporal and dredging-related changes on the study plots were mapped using MDS. MDS plots a measure of similarity between objects into 2 or more dimensional space so that distances between objects correspond closely to their input similarities. While the computational algorithm for MDS is complex, the graphical representation is easily communicated (Clarke 1993), and ecologically meaningful patterns become more apparent (Gamito \& Raffaelli 1992). The PATN computer package (Belbin 1990) was employed for the non-metric MDS ordinations used in this study. MDS plots were calculated using the triangular matrix of dissimilarities generated from $\mathrm{B}-\mathrm{C}$ dissimilarity measures calculated for all 18 plot $x$ date combinations ( 2 plots $x$ 9 dates), using double square root transformed data. 
Marked differences between communities on the eastern and western halves of the experimental plots were found. Consequently separate MDS plots were also calculated using B-C dissimilarities based on the double square root of the total number of individuals of each species found on each half of the plots for the 9 dates sampled. MDS plots were also used to summarise differences between both halves of the plots. Following double square root transformations of all abundance data, B-C dissimilarities of all grab samples taken on the east and west of the control plot were incorporated into an MDS plot, as were the B-C dissimilarities of all grab samples taken on the east and west of the control and dredge plots in the pre-dredging period.

For the 10 most abundant species, differences between the number of individuals found on each plot (and each half plot) before and after dredging were examined using a $\mathrm{BACl}$ experimental design (see Stewart-Oaten et al. 1986). Statistical significance of the dredging impact was tested using nested analysis of variance (ANOVA) in which plot $x$ time interactions were tested against the mean square for the plot $x$ date(time) term. This test is equivalent (Underwood 1991, his Table 2c) to the $t$-test recommended by Stewart-Oaten et al. (1986). An additional analysis, similar to that described in Underwood (1991), but including a sediment covariate ( $\%$ sediment $<63 \mu \mathrm{m}$ ), was undertaken for those species for which this covariate was significant, after a preliminary ANOVA demonstrated that dredging caused no significant change to sediment type on the plots $(p=0.75$ for plot $x$ time interaction). Homogeneity of variance was examined using Cochran's test and heterogeneity removed by $\log _{10}(n+1)$ and $1 /(n+1)$ transformations. To provide an objective test of the persistence of dredging impacts ANOVAs were performed progressively with $3,4,5$, and 6 post-impact sampling dates.

To determine whether different categories of species were more or less vulnerable to dredging, species were grouped by taxonomic affinity, feeding type, their proximity to the sediment surface and their rarity. ANOVAs of these different groupings were undertaken using data for the entire plots and 3 post-dredging dates. Three post-dredging dates were included as fewer dates had less power, and more dates provided too much time for recovery. A sediment covariate (\% sediment $<63 \mu \mathrm{m})$ was included in the statistical model, although in most cases inclusion of this variable had a minimal effect on significance levels. Cochran's test was used to ensure that a $\log _{10}(n+1)$ transformation removed significant heterogeneity from variances of all species groups, but it was necessary to exclude 2 very contagiously distributed species, the bivalve Theora cf. lubrica (Sp. rank 17) and the scavenging ostracod Empoulsenia sp. 1 (Sp. rank 27) from these analyses.
Species were grouped by phylum and class to test for any influence of taxonomic affinity. Species were also divided into 4 feeding types: deposit feeders, predators, scavengers and suspension feeders. Feeding categories of molluscs were based on Poore \& Rainer (1974), while feeding categories of other taxa were slightly modified from those used by Wilson et al. (1993), which were themselves based on Brusca \& Brusca (1990) and Fauchald \& Jumars (1979). There were no direct data on the microdistribution of species in the top $5 \mathrm{~cm}$ of surface sediments most disturbed by dredges (Black \& Parry 1994); consequently, depthrelated groupings were based on the degree to which 27 of the 30 most common species were over- or underrepresented in net samples taken in the dredge plume. Three species of mysids found amongst these 30 species were not included in this analysis as they do not occur in the sediment. Four categories of 'depth within the sediment' were based on ratios of relative abundance of species netted in the dredge plume versus their abundance in the benthos: ratio $>1.0=$ surface layer; $0.5<$ ratio $<1.0=$ near surface layer $; 0.1<$ ratio $<$ 0.5 = below surface; and ratio $<0.1=$ well below surface layer. To assess whether rare and abundant taxa were impacted similarly, all species were ranked by their abundance during the 17 mo of the study and grouped into 5 abundance classes: Sp. 1-10, Sp. 11-20, Sp. 21-30, Sp. 31-50, Sp. 51-247

As a final step, where there was no significant change in abundance of individual species or a group of species, 2 power values were calculated, the first to detect a decrease (or increase) of $30 \%$ and the second to detect a decrease of $50 \%$ following dredging. These power values were calculated using the $t$-test equivalent of the ANOVA method used elsewhere in this paper. Thus no provision was made for the inclusion of the sediment covariate in these power calculations.

Estimates of the percentage change in the abundance of individual species and of different species groupings were calculated using the 3 pre-dredging samplings and the first 3 post-dredging samplings. Percentage change was estimated from the difference between ratios of the sum of individuals on plots before and after dredging:

$$
\% \text { Difference }=\left[\left(\mathrm{n}_{\mathrm{da}}-\mathrm{n}_{\mathrm{ca}} / \mathrm{n}_{\mathrm{ca}}\right)-\left(\mathrm{n}_{\mathrm{db}}-\mathrm{n}_{\mathrm{cb}} / \mathrm{n}_{\mathrm{cb}}\right)\right] \times 100
$$

where $\mathrm{n}$ is the sum of the number of individuals in the 3 sampling times either before or after dredging, and the subscripts are as follows: $c$ is control plot; $d$ is dredge plot; $a$ is after dredging; $b$ is before dredging.

Conventionally the null hypothesis is rejected (a result is considered 'statistically significant') if the probability of the null hypothesis being true is less than 1 in $20(\mathrm{p}<0.05)$. In this study a result is considered 'significant' if $p<0.10$. This convention was 
adopted because in this study the cost of making a Type II error was considered as important as making a Type I error. Failure to detect a real change due to dredging (Type II error) was considered as serious a problem as identifying a change due to dredging when none had occurred (Type I error) (Cohen 1988, Peterman 1990, Peterson 1993)

\section{RESULTS}

\section{Physical changes to sea floor}

Before the experimental dredging, bedforms within the control and dredge plots were dominated by lowrelief mounds and depressions formed by callianassids. The cone shaped mounds of sediment excavated by these shrimps were up to $100 \mathrm{~mm}$ high and $230 \mathrm{~mm}$ in diameter, but averaged $42 \mathrm{~mm}$ in height, $152 \mathrm{~mm}$ in diameter and had an average density of $1.2 \mathrm{~m}^{-2}$ (Table 2). Adjacent pits and depressions often trapped detached seagrasses and algae. Epifauna was sparse and dominated by 40 to $80 \mathrm{~mm}$ scallops.

Observations made $8 \mathrm{~d}$ after the experimental dredging indicated that only the dredge plot had changed markedly. Most of the sea floor within the dredge plot was very flat. Dredges had a grader-like impact, callianassid mounds were removed and depressions filled, but most callianassids appeared to have survived. There were many callianassid mounds being rebuilt (cf. Peterson 1977) and the density of callianassids taken in grabs on the dredge plot did not change significantly in the 3 mo following dredging. The density of Callianassa arenosa was 0.13 ( $\pm 0.05 \mathrm{SE})$ before and $0.11( \pm 0.05 \mathrm{SE})$ in the $3.5 \mathrm{mo}$ after dredging and the density of Upogebia dromana was 0.09 ( $\pm 0.07 \mathrm{SE}$ ) and $0.02( \pm 0.02 \mathrm{SE})$ after dredging. Narrow undredged strips occupied approximately $10 \%$ of the area of the dredge plot. Parallel tracks from dredge skids (up to $25 \mathrm{~mm}$ deep) were observed throughout the flattened regions of the plot and drifting seaweed was no longer apparent. The number of large scallops within the dredge plot was reduced although small scallops remained plentiful. Small numbers of the ascidian Pyura

Table 2. Density and size of callianassid mounds on two $50 \times$ $1 \mathrm{~m}$ transects on the control plot on 16 August 1992

\begin{tabular}{|lccc|}
\hline Transect & $\begin{array}{c}\text { Density } \\
\left(\text { no. } \text { m }^{-2}\right)\end{array}$ & $\begin{array}{c}\text { Mean height } \\
(\mathrm{mm})\end{array}$ & $\begin{array}{c}\text { Mean diameter } \\
(\mathrm{mm})\end{array}$ \\
\hline 1 & 1.00 & 33 & 169 \\
2 & 1.43 & 51 & 135 \\
Mean & 1.22 & 42 & 152 \\
\hline
\end{tabular}

stolonifera were observed on the surface of the sediments where they had been discarded from dredges and a small number of dead pebble crabs Philyra undecimspinosa were found.

One month after the experimental dredging, the sea floor within the dredged plot remained flat, and dredge tracks could still be distinguished. Six months after dredging, dredge tracks were no longer visible, and callianassid mounds were abundant and appeared similar in size to those which had been present before dredging. Depressions had reformed throughout the plot and now contained scallops and detached weed. However, while the dredged plot resembled its predredging appearance, flat areas were still visible between adjacent mounds and pits. Eleven months after dredging, the callianassid mounds appeared similar on the control and dredge plots and any differences in topography between the plots were no longer distinguishable by a diver.

Colour-coded depth rings recovered by dredges indicated that dredges typically disturbed the top 20 $\mathrm{mm}$ of sediment but could penetrate up to $60 \mathrm{~mm}$ into the sediments (see Black \& Parry 1994 for details).

\section{Depth distribution of infauna prior to dredging}

Most $(68 \%)$ ) organisms occurred in the top $5 \mathrm{~cm}$ of sediment, a further $22 \%$ occurred at a depth of between 5 to $10 \mathrm{~cm}$, and only $9 \%$ occurred in sediments deeper than $10 \mathrm{~cm}$ (Table 3).

\section{Infauna dredged from sediments}

Comparison of the relative abundance of species netted in the sediment plume with their relative abundance in the benthos immediately before dredging ( 2 July 1991 ) indicated that many species were netted significantly $\left[\chi^{2}(28)=14646, p \ll 0.01\right]$ more or less frequently than expected (Fig. 2). Ratios of the relative abundance of each taxon in the net compared to its relative abun-

Table 3. Number of organisms in different depth strata of sediment cores taken within a $2500 \mathrm{~m}^{2}$ area on the control plot at St. Leonards on 11 April 1994

\begin{tabular}{|lrrrrc|}
\hline $\begin{array}{l}\text { Depth stratum } \\
(\mathrm{mm})\end{array}$ & A & B & C & D & Total \\
\hline Top 50 & 24 & 6 & 21 & 38 & $89(68 \%)$ \\
$50-100$ & 3 & 12 & 6 & 8 & $29(22 \%)$ \\
$100-200$ & 1 & 4 & 1 & 6 & $12(9 \%)$ \\
Total & 28 & 22 & 28 & 52 & 130 \\
\hline
\end{tabular}




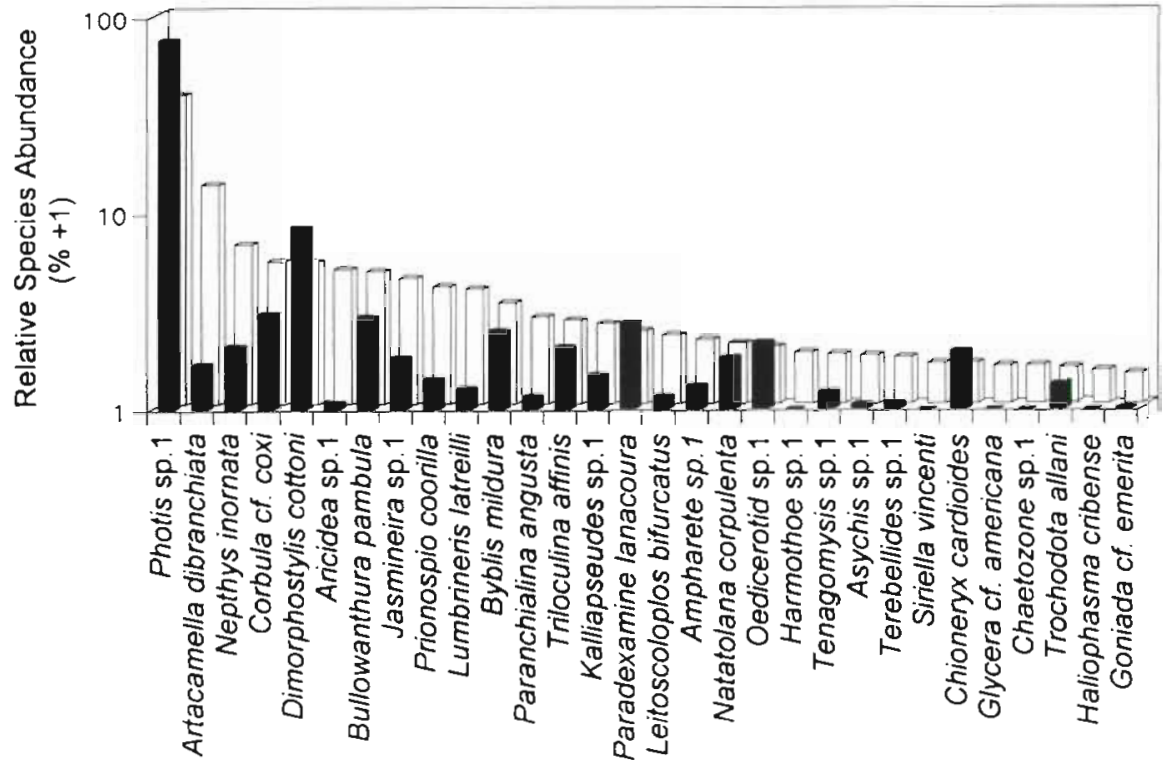

Fig. 2. Relative abundances of the 30 most abundant species taken in a net in the dredge plume (black) and in the benthos immediately before the experimental dredging (white). To enable use of a logarithmic scale, 1 was added to all percentages dance in the benthos (Fig. 2) were used to subdivide species into 4 categories: 'over-represented' (ratio $>1.0$ ), 'probably over-represented' $(0.5<$ ratio $<1.0)$, 'probably under-represented' $(0.1<$ ratio $<0.5)$ and 'under-represented' (ratio < 0.1). Photis sp. 1, Dimorphostylis cottoni, Paradexamine lanacoura, Oedicerotid sp. 1, and Chioneryx cardioides were 'over-represented' in the net; Bullowanthura pambula, Byblis mildura, Triloculina affinis, Natatolana corpulenta and Trochodota allani were
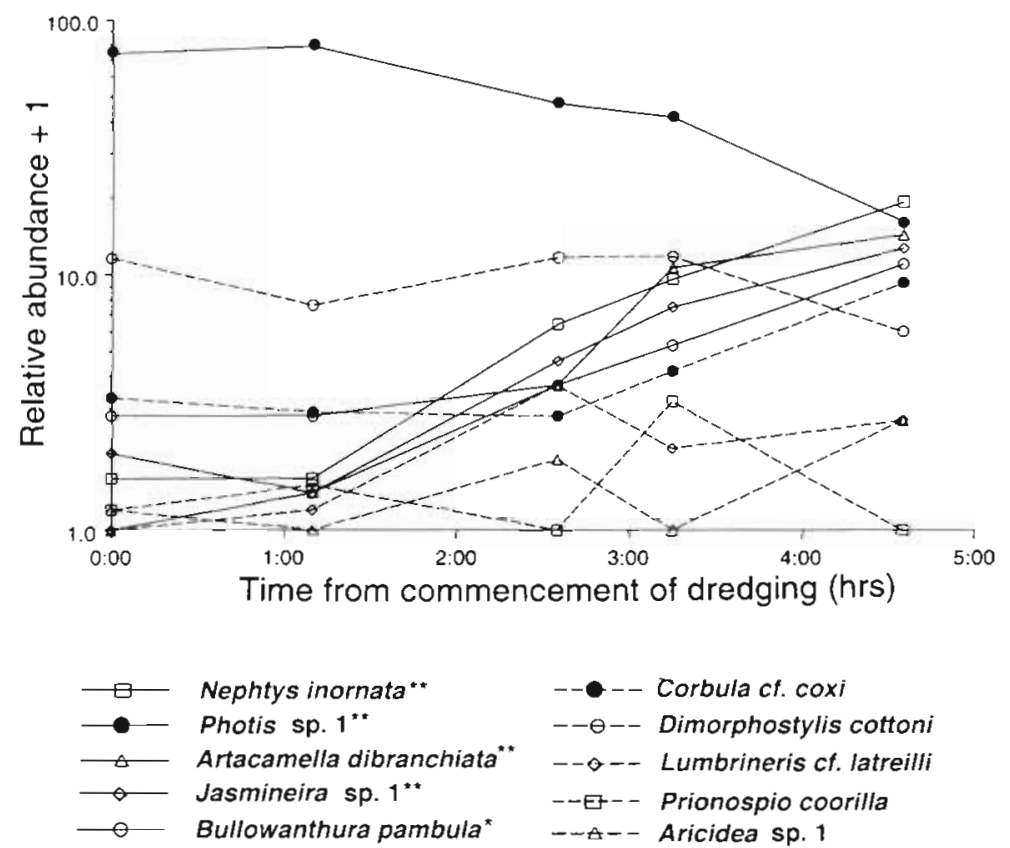

Fig. 3. Relative abundances of the 10 most abundant species taken in a net in the dredge plume at different times during experimental dredging. Species whose relative abundance changed significantly during dredging are indicated: " $p<0.10, \cdots p<0.05$ 'probably over-represented', whereas Nephtys inornata, Corbula cf. coxi, Jasminiera sp. 1, Prionospio coorilla, Kalliapseudes sp. 1, Leitoscolopolos bifurcatus, Ampharetesp. 1, Tenagomysis sp. 1 and Terebellides sp. 1 were 'probably under-represented'; Artacamella dibranchiata, Aricidea sp. 1, Lumbrinereis cf. latreilli, Paranchialina angusta, Harmothoe sp. 1, Asychis sp. 1, Siriella vincenti, Glycera cf. americana, Chaetozone sp. 1, Haliophasma cribense and Goniada cf. emerita were 'underrepresented'. The relative abundance of 5 of the 10 most common species caught in the net changed significantly during the first $2 \mathrm{~d}(5 \mathrm{~h})$ dredging (Fig. 3). Photis sp. 1 was significantly more abundant during the early drags whereas in late drags $A$. dibranchiata, $B$. pambula, Jasminiera sp. 1 and $N$. inornata became significantly more abundant (Fig. 3)

Photis sp. 1, a tube-building amphipod, and Dimorphostylis cottoni, a cumacean, both occur in the surface sediments and were 'over-represented' in net samples (Fig. 2) particularly during the early drags (Fig. 3). Other species which appeared to be 'over-represented' in net samples were 3 amphipods Byblis mildura, Paradexamine lanacoura, Oedicerotid sp. 1, an isopod Natatolana corpulenta, a holothurian Trochodota allani, a foram Triloculina affinis, a bivalve Chioneryx cardoides, and a paranthurid isopod Bullowanthura pambula (Fig. 2). The first 4 of these are actively swimming crustaceans likely to occur in the surface sediments, while $T$. allani is frequently found adhering to divers' wet suits, indicating that this species too is abundant 
in the surface sediments. The foram $T$, affinis probably occurs in surface sediments but the distributions of $C$. cardoides and B. pambula are unknown. Species which appeared to be 'under-represented' in net samples were predominantly polychaetes (14 spp.) most of which occur in burrows: 3 were mysids, Tenagomysis sp. 1, Paranchialina angusta, and Siriella vincenti, and the remaining species were a tanaid, Kalliapseudes sp. 1, an anthurid isopod, Haliophasma cribense, and a bivalve, Corbula cf. coxi. The burrowing polychaetes Artacamella dibranchiata, Nephtys inornata, Aricidea sp. 1, Jasmineira sp. 1, and Lumbnrinereis cf. latreilli were all more abundant in late drags (Fig. 3); these burrowing species appear to become progressively more vulnerable as the surface sediments are removed. Mysids do not occur in the sediment and may be able to avoid the net. The depth distributions of the isopods and the bivalve which appeared to be underrepresented are unknown.

\section{Changes to benthic community structure}

A total of 247 invertebrate species (see Currie \& Parry 1994 for a species list) and 107518 individuals were collected at the $2 \mathrm{St}$. Leonards plots during this study. There were $99(40 \%)$ crustaceans collected, 60 $(24 \%)$ polychaetes, $46(19 \%)$ molluscs, and $42(17 \%)$ members of other phyla. The amphipod Photis sp. 1 was the most abundant species and contributed $22 \%$ of the animals collected.

Before the experimental dredging, the numbers of species on the control and dredge plots were very similar (Fig. 4A; 135 vs 134 on 8 April 1991, 128 vs 122 on 13 May 1991, and 115 vs 114 on 2 July 1991), but following the experimental dredging there was a significant decrease in the number of species on the dredge plot which persisted for $14 \mathrm{mo}$ (non-independent ANOVAs including 3, 4, 5, and 6 post-dredging sampling dates, $0.03<p<0.08$ ). After 14 mo the number of species on the dredge plot slightly exceeded the number on the control plot (Fig. 4A), but the number of species shared between both plots (Fig. 4A) was reduced following dredging $(111,100$ and 97 species before vs $84,82,94,91,129$ and 90 species after dredging). Over the period of the study a total of 60 species were always found on the control plot, while only 53 were always found on the dredge plot.

The total number of individuals of all species sampled at both plots remained relatively constant before dredging, although there were slightly fewer animals collected on the control plot 2 mo before dredging (Fig. 4B). The number of individuals on both plots more than doubled in the 5 to 8 mo following the experimental dredging and then decreased again over the follow-
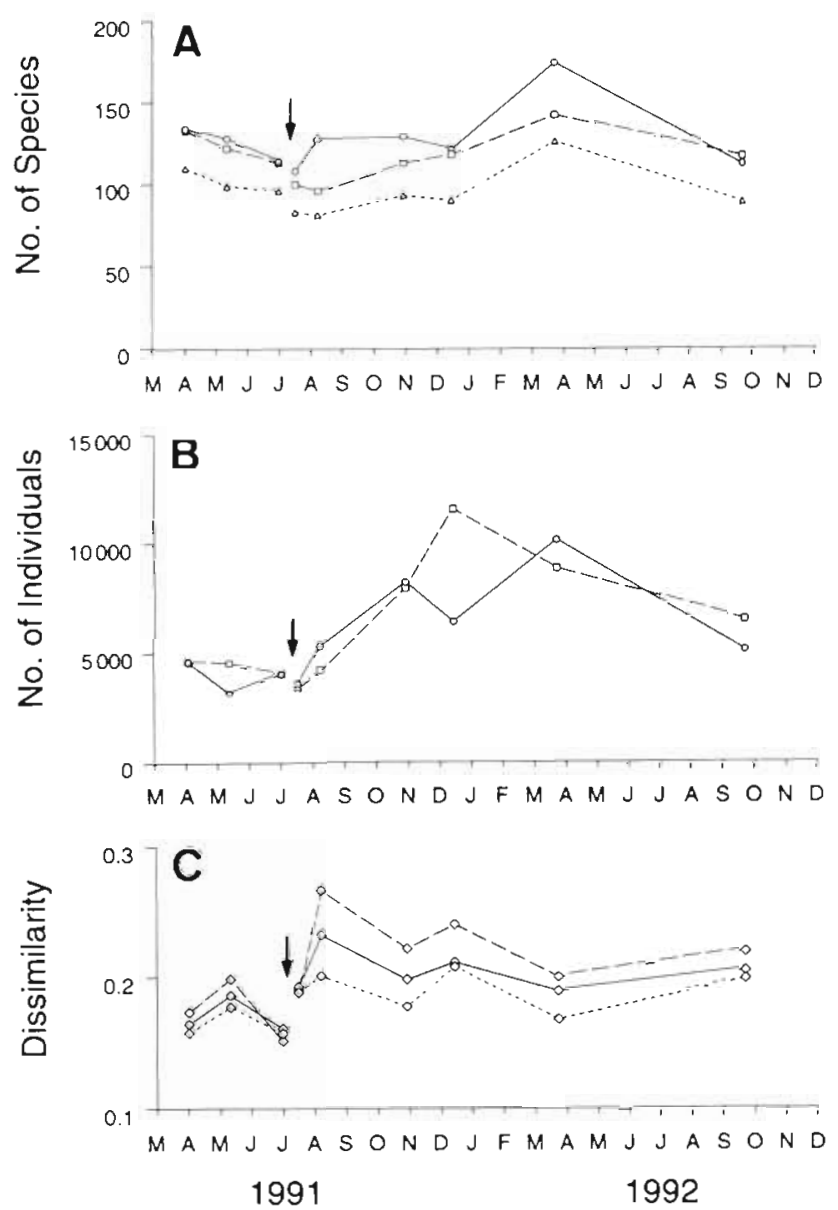

Fig. 4. Differences between control and dredge plots before and after dredging. (A) Changes in number of species on (O) control plot, (D) dredge plot, $(\Delta)$ both plots; (B) changes in number of individuals on (O) control plot, ( $\square$ ) dredge plot; (C) Bray-Curtis dissimilarity between plots, using the following transformations: $(--)$ presence/absence; $(-)$ double square root; (----) square root. Arrows indicate time of dredging

ing 6 to 9 mo. The increases in abundance following dredging are largely the result of recruitment of juveniles, particularly Photis sp. 1 and Jasmineira sp. 1. Differences between the total number of individuals on the control and dredge plots did not change significantly in the 3.5 mo following dredging or thereafter (ANOVAs, $\log \left(\mathrm{n}_{\mathrm{c}}-\mathrm{n}_{\mathrm{d}}\right)$ for 3 pre-dredging and $3,4,5$, and 6 post-dredging dates, $\mathrm{p}>0.10$ ).

B-C dissimilarities calculated using 3 different data transformations (square root, double square root and presence/absence; Fig. 4C) all increased significantly following experimental dredging and persisted for $14 \mathrm{mo}$, the duration of the study (ANOVAs including 3 , 4, 5, and 6 post-dredging sampling dates, $0.007<\mathrm{p}<$ 0.03 ). In the post-dredging period, except with the square root data transformation, the 2 plots were most different 3 wk after dredging (Fig. 4C). 


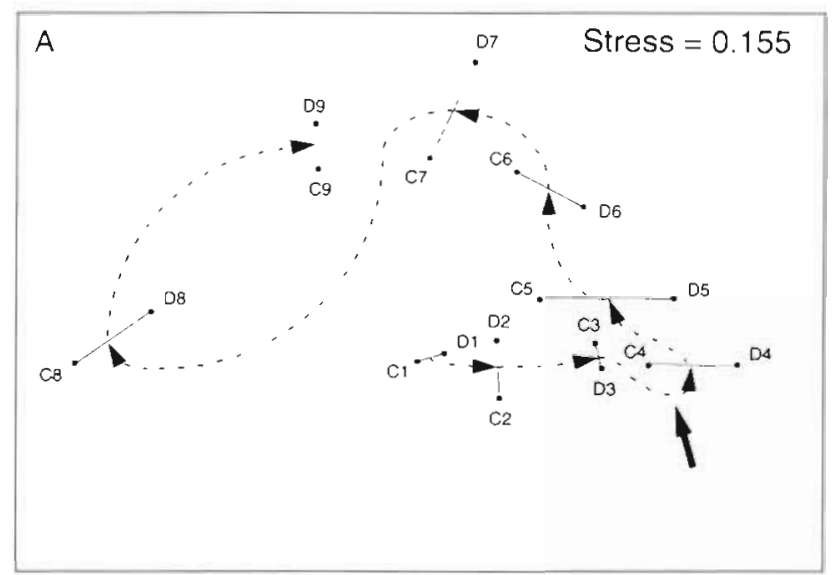

Fig. 5. MDS ordinations of grab samples on (A) the control (C) and dredge (D) plots on each sampling date (1 to 9) and (B) the western and eastern halves of the plots on each sampling date. Solid lines measure the dissimilarity between control and dredge plots at each sampling date. Broken arrow line shows the temporal sequence of sampling: large arrow indicates time of experimental dredging

\section{Multidimensional scaling}

The MDS ordination (Fig 5A) maps the spatial and temporal changes in benthic community structure on the control and dredge plots before and after dredging. The stress coefficient of 0.155 indicates that the ordination is not unduly distorted (Clarke 1993) and is a fair representation of the input dissimilarities in $2 \mathrm{di}$ mensions.

The MDS ordination summarises many of the changes on the control and dredge plots noted above. The lengths of the lines C-D in Fig. 5A provide a measure of the dissimilarity between the dredge and control plots through time. Short lines connect the control and dredge plots for the 3 pre-dredging sampling dates (C1-D1, C2-D2 and C3-D3). But immediately following dredging, the lengths of the $C-D$ lines increase until they reach a maximum $3 \mathrm{wk}$ after dredging (C5-D5) when the plots are at their most different. Subsequent changes to the lengths of the $\mathrm{C}-\mathrm{D}$ lines indicate that the plots gradually become more similar. The broken line in Fig. 5A indicates that both the control and dredge plots follow a similar temporal trajectory representing seasonal and interannual changes on both plots. Temporal changes occurred progressively over the 17 mo of the study and there was little evidence of cyclical seasonal changes. Previous studies of benthos in Port Phillip Bay (Poore \& Rainer 1979) also found that interannual changes were greater than seasonal changes. The second to the last last sampling

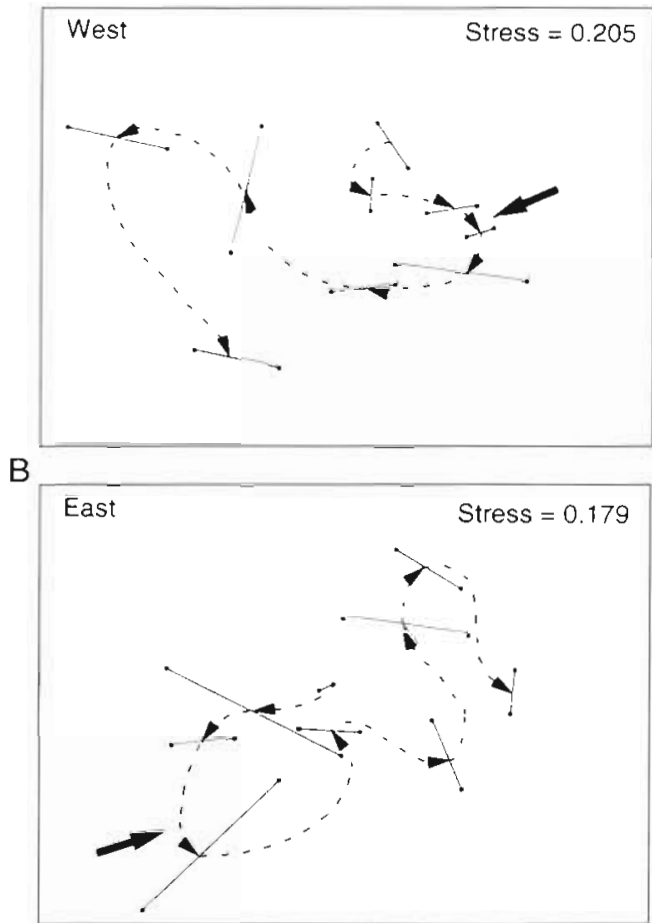

date was the most divergent as a result of recruitment of many species at this time (see Fig. 4A).

The western and eastern halves of the study plots show patterns of change similar to those of the whole plots (Fig. 5A, B). The maximum difference between the control and dredge plots occurred $3 \mathrm{wk}$ after dredging on both the entire plots and the western halves. In contrast the maximum difference between the eastern halves of the control and dredge plots occurred immediately after dredging. It is not clear whether this indicates that impacts were noticed more quickly in the softer sediments on the eastern half of the dredge plot or merely that the changes observed on the eastern halves are less reliable as these half plots straddled a large environmental gradient (see Figs. $6 \& 7$ ).

\section{Spatial variation across the study plots}

A pronounced ecological gradient was detected between the easterm and western edges of both the control and dredge plots (Fig. 6). There were more species (Fig. 6A) and individuals (Fig. 6B) on the western than on the eastern sides of both plots. These differences were also seen in the distribution of many species, most of which were much more abundant on the western than on the eastern halves of the plots.

The gradient in abundance and number of species across the plots parallelled physical changes across 
the plots. Depth increased from west to east across the plots, although the recorded gradient from $12 \mathrm{~m}$ on the west to $15 \mathrm{~m}$ on the east (Fig. 6C) was greater than the actual change in depth, as recorded values
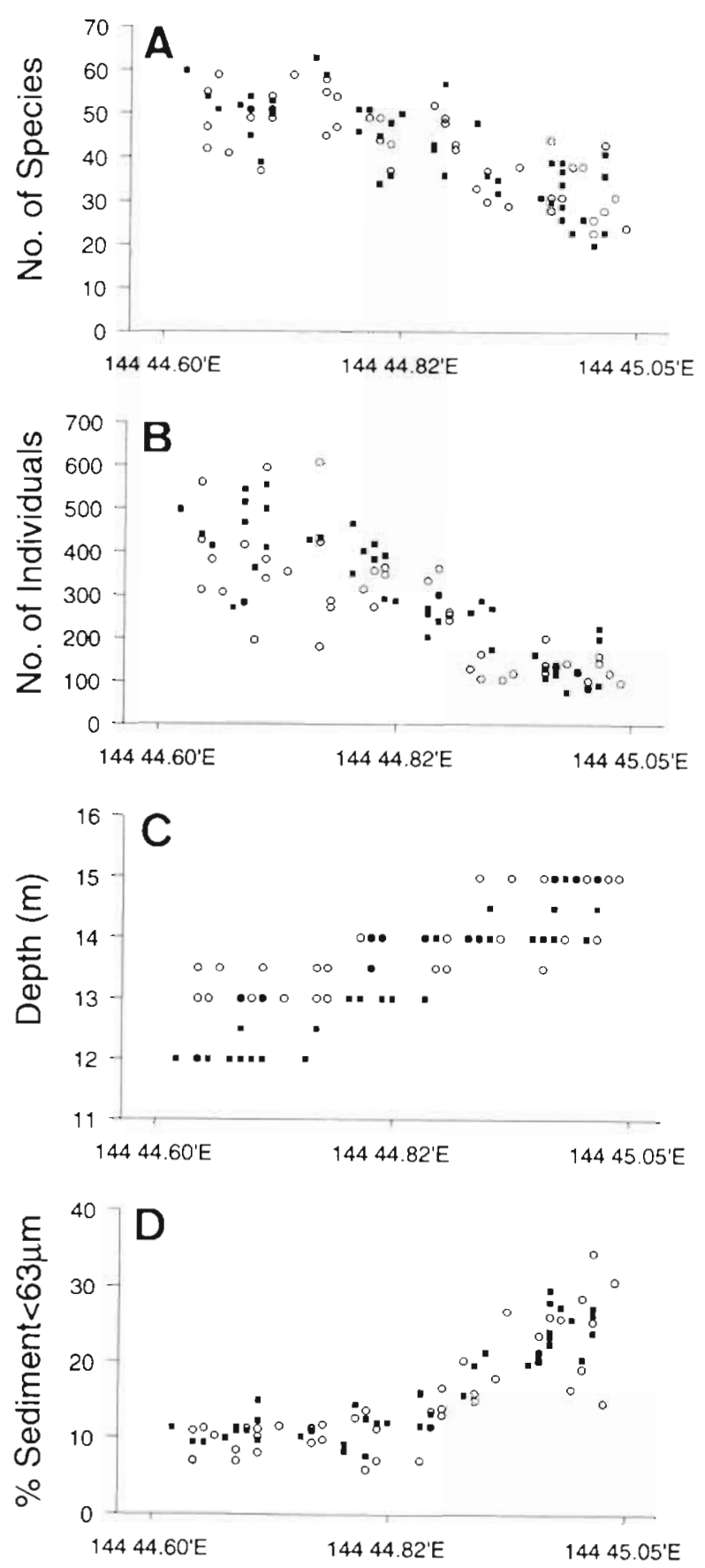

\section{Longitude}

Fig. 6. East-west gradients across the control $(0)$ and dredge (a) plots. (A) number of species; (B) number of individuals; (C) depth; (D) sediment type were not corrected for a $1 \mathrm{~m}$ tidal variation. The amount of mud (sediment fraction $<63 \mu \mathrm{m}$ ) in the sediment increased from $10 \%$ in the west to $30 \%$ in the east (Fig. 6D).

Most of the variation across the $600 \mathrm{~m}$ width of the study plots occurred across the eastern halves of the plots; there was little or no gradient across the western half of either plot. This was particularly evident with the change in mud content, which varied little across the western halves of both plots but changed markedly across the eastern halves (Fig. 6D). Gradients in species number and total number of individuals were also sharper in the eastern half than in the western half of each plot (Fig. 6A, B)

This east-west gradient was clearly seen from the distribution of many individual species across the plots and from MDS ordination of communities taken in grabs on the eastern and western halves of each plot. All grab samples taken on the western half of the control plot were very similar, whereas there was
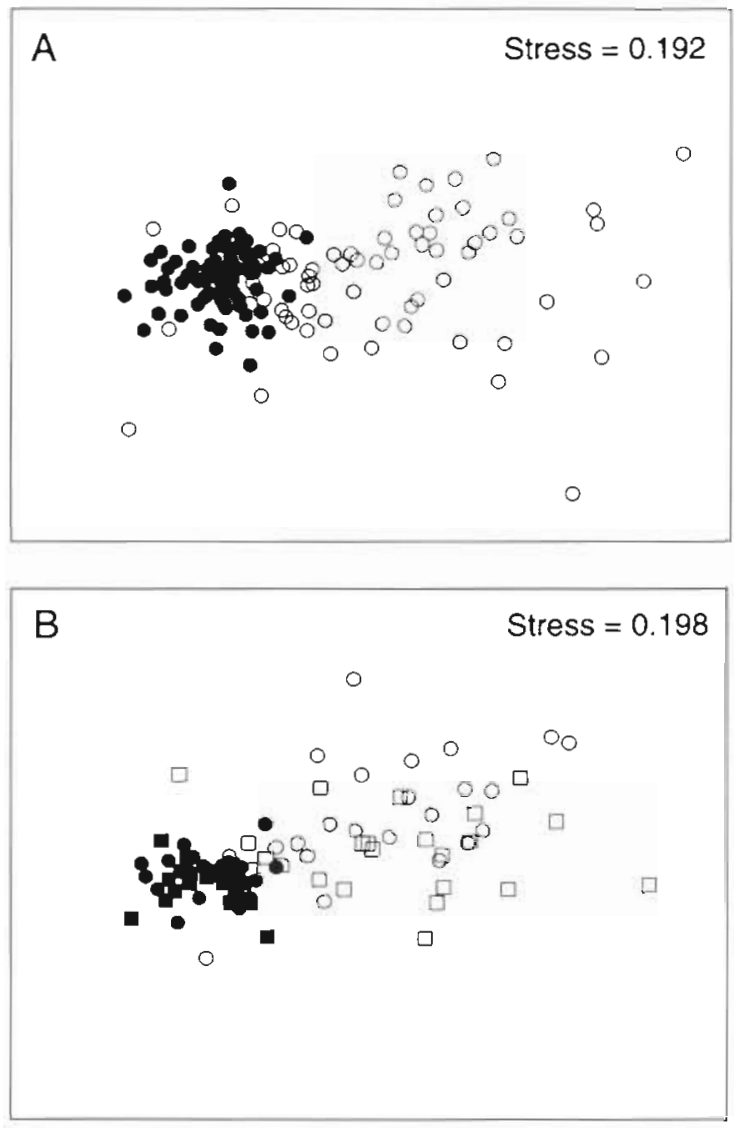

Fig. 7 MDS ordinations of (A) all grab samples taken on the western (O) and eastern $(O)$ halves of the control plot; $(B)$ grab samples taken during the pre-dredging period on the western (-) and eastern (O) halves of the control plot and the western $(\square)$ and eastern ( $\square$ ) halves of the dredge plot 
much greater variation in grab samples taken on the eastern half (Fig 7A). A similar pattern was apparent using MDS ordination of all grab samples taken on the 3 pre-dredging sampling dates. Grab samples taken on the western halves of the control and dredge plots were very similar, whereas grabs taken in the eastern halves were much more variable (Fig 7B).
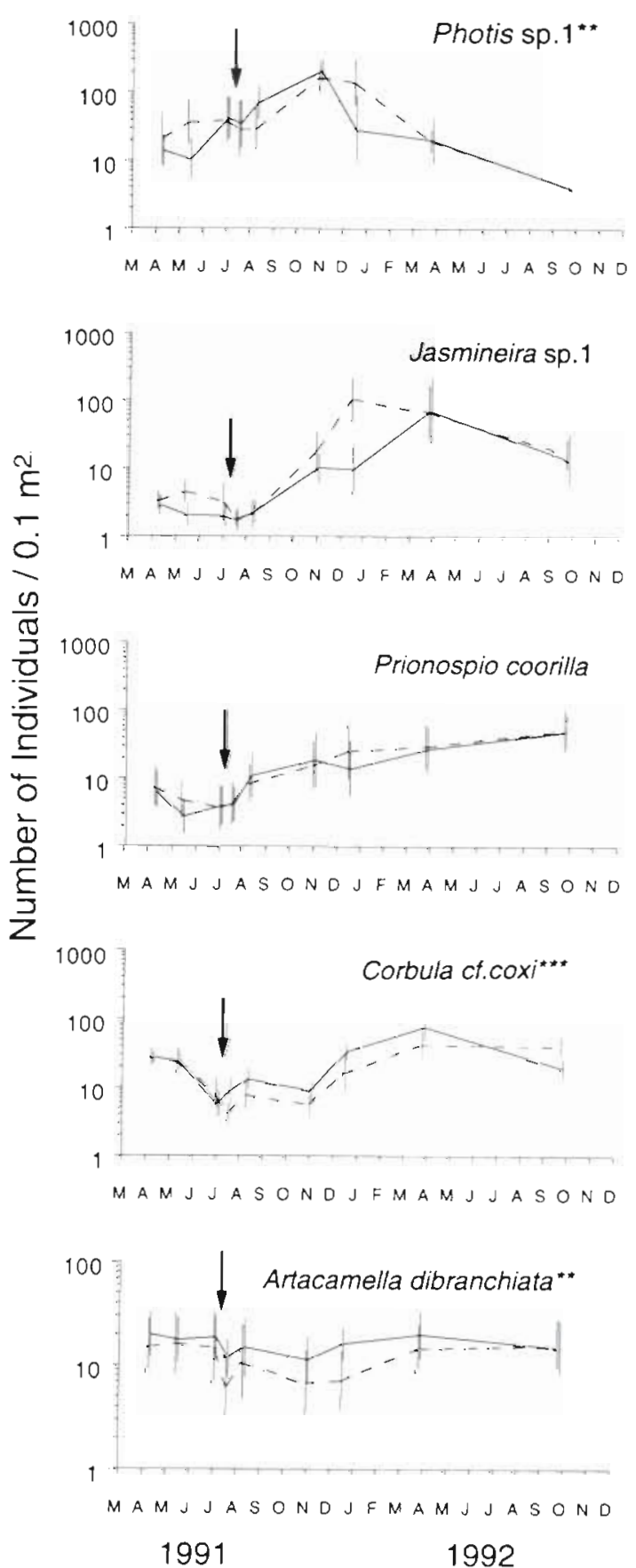

The gradient across both the control and dredge plots was similar for all the parameters discussed above, indicating that the experimental plots were well-matched. However, the marked east-west gradient across both plots led to separate statistical analyses being undertaken for the eastern and western halves of the plots as well as for the entire plots.
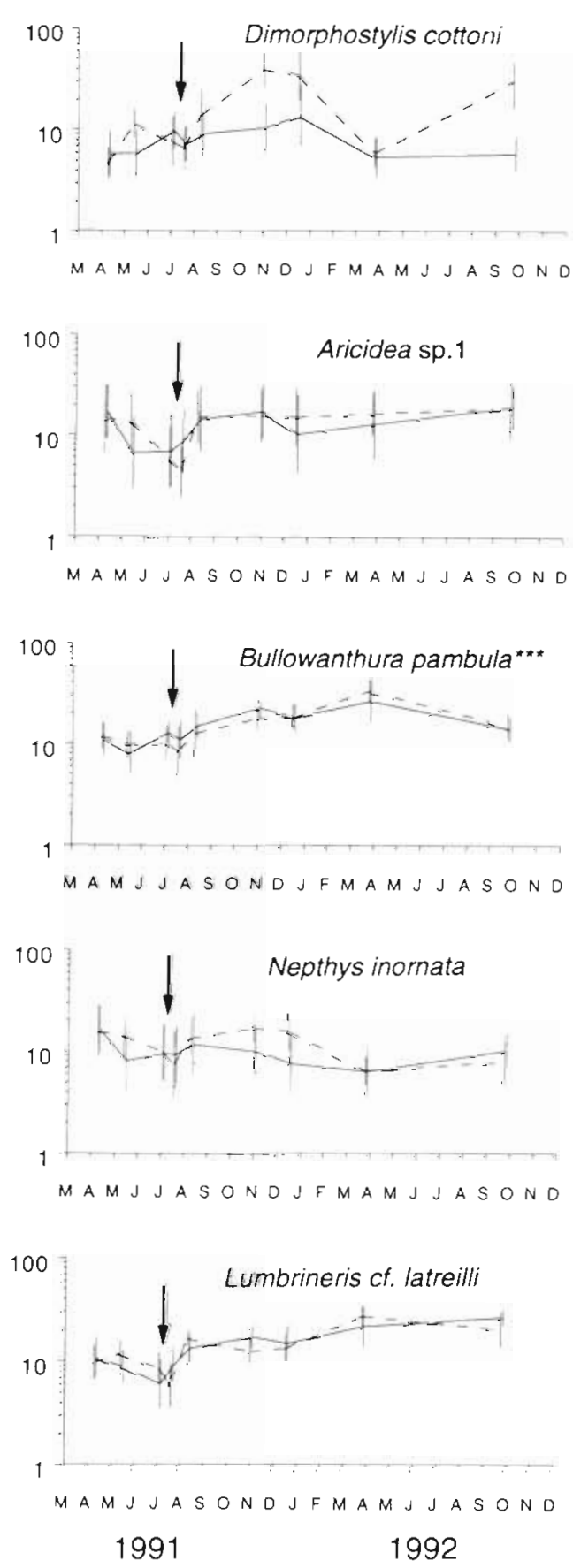

Fig. 8. Change in abundance of the 10 most common species on the control ( - ) and dredge (- - ) plots before and after dredging. Error bars show SE. Arrows indicate time of experimental dredging. Species that changed in abundance significantly across the entire plots in the 3.5 mo following dredging are marked $\cdots p<0.05, \cdots p<0.01$. 


\section{Changes in abundance of individual species}

Changes to the abundance of the 10 most common species found during the 17 mo of the study were considered in detail. These species in order of abundance were: Photis sp. 1 (corophid amphipod), Jasmineira sp. 1. (sabellid polychaete), Prionospio coorilla (spionid polychaete). Corbula cf. coxi (corbulid mollusc), Artacamella dibranchiata (terebellid polychaete), Dimorphostylis cottoni (diastylid cumacean), Aricidea sp. 1 (paraonid polychaete), Bullowanthura pambula (paranthurid isopod), Nephtys inornata (nephtyid polychaete), and Lumbrineris cf. Latreilli (lumbrinerid polychaete). Changes in abundance of these 10 species on the control and dredge plots throughout the 17 mo of the study are shown in Fig. 8. Significance levels for plot $\times$ period interactions for ANOVAs including the 3 pre-dredging sampling dates and 3 post-dredging sampling dates $(3.5 \mathrm{mo}$ ) are shown in Table 4. Estimates of the percentage change in the mean abundance of each species over the same period are shown in Table 5. The duration of dredging impacts on these species was determined from the number of postdredging sampling dates that resulted in significant interactions beyond the initial 3.5 mo post-dredging period and are shown in Table 6

The likelihood of detecting significant changes in the abundance of a species following dredging depends on

Table 4. Probability levels for ANOVAs for 12 common species including 3 sampling dates before and 3 sampling dates after dredging for plot $\times$ time interactions tested against plot $\times$ date(time) terms. Separate analyses are provided for entire plots and eastern and western halves, in all cases with and without a covariate (percentage of sediment $<63 \mu \mathrm{m}$ ) and for the covariate 1 tself All abundance data were transformed using $\log _{10}(n+1)$, except for Jasmineira sp. 1 where a $1 /(n+1)$ transformation was used

\begin{tabular}{|c|c|c|c|c|c|c|c|c|c|c|}
\hline \multirow[t]{2}{*}{ Species } & \multirow[t]{2}{*}{ Rank. } & \multicolumn{3}{|c|}{ Entire plot } & \multicolumn{3}{|c|}{ Western half } & \multicolumn{3}{|c|}{ Eastern half } \\
\hline & & $-\mathrm{Cov}$ & $+\mathrm{Cov}$ & Cov & $-\operatorname{Cov}$ & $+\mathrm{Cov}$ & Cov & $-\mathrm{Cov}$ & $+\mathrm{Cov}$ & Cov \\
\hline Photis sp. 1 & 1 & 0.1038 & 0.0338 & 0.0001 & 0.1287 & 0.1514 & 0.2246 & 0.0793 & 0.0370 & 0.0001 \\
\hline Jasmineira sp. 1 & 2 & 0.1515 & 0.1288 & 0.0001 & 0.5013 & 0.4936 & 0.7336 & 0.0696 & 0.1057 & 0.0008 \\
\hline Prionospio coorilla & 3 & 0.1750 & 0.1646 & 0.0001 & 0.0344 & 0.0502 & 0.0023 & 0.9592 & 0.7336 & 0.0001 \\
\hline Corbula cf. coxi & 4 & 0.0091 & 0.0093 & 0.8839 & 0.0045 & 0.0057 & 0.3443 & 0.0360 & 0.0544 & 0.0001 \\
\hline Artacamella dibranchiata & a 5 & 0.0479 & 0.4388 & 0.0001 & 0.7571 & 0.8616 & 0.1952 & 0.0702 & 0.0681 & 0.8367 \\
\hline Dimorphostylis cottoni & 6 & 0.3937 & 0.3818 & 0.0001 & 0.0635 & 0.0544 & 0.0515 & 0.9115 & 0.9616 & 0.0001 \\
\hline Ancidea sp. 1 & 7 & 0.3593 & 0.2085 & 0.0001 & 0.0477 & 0.0419 & 0.7894 & 0.8847 & 0.7007 & 0.0001 \\
\hline Bullowanthura pambula & 8 & 0.1750 & 0.0045 & 0.0001 & 0.7909 & 0.8048 & 0.4375 & 0.2290 & 0.0965 & 0.0001 \\
\hline Nephtys inornata & 9 & 0.9185 & 0.6730 & 0.0001 & 0.1794 & 0.1754 & 0.1020 & 0.0891 & 0.9982 & 0.0001 \\
\hline Lumbrineris cf. latreilli & 10 & 0.2083 & 0.2240 & 0.0001 & 0.1074 & 0.1069 & 0.6922 & 0.2431 & 0.2860 & 0.0001 \\
\hline Natatolana corpulenta & 14 & 0.3411 & 0.3509 & 0.1979 & 0.2120 & 0.2465 & 0.4570 & 0.7586 & 0.7698 & 0.2313 \\
\hline Oedicerotidsp. 1 & 16 & 0.0760 & 0.1651 & 0.0001 & 0.0484 & 0.0515 & 0.8557 & 0.2863 & 0.2398 & 0.0001 \\
\hline
\end{tabular}

Table 5. Pre-dredging differences between dredge and control sites and \% change in abundance in the 3.5 mo following dredging for 12 common species. Changes are shown for entire plots and their western and eastern halves. Significant changes are shown: $\cdot p<0.10, \cdots p<0.05, \cdots p<0.01$. Power to detect changes of 30 and $50 \%$ shown where changes were non-significant (ns)

\begin{tabular}{|c|c|c|c|c|c|c|c|c|c|c|c|}
\hline \multirow[t]{3}{*}{ Species } & \multirow[t]{3}{*}{ Rank } & \multirow{3}{*}{$\begin{array}{c}\% \text { Difference } \\
\text { pre-dredging } \\
\text { Entire }\end{array}$} & \multirow{2}{*}{\multicolumn{3}{|c|}{$\begin{array}{l}\% \text { Change } \\
\text { post-dredging }\end{array}$}} & \multicolumn{6}{|c|}{ Power, $\alpha=0.10$} \\
\hline & & & & & & \multicolumn{3}{|c|}{$\begin{array}{c}30 \% \text { decrease or } \\
\text { (increase) }\end{array}$} & \multicolumn{3}{|c|}{$\begin{array}{c}50 \% \text { decrease or } \\
\text { (increase) }\end{array}$} \\
\hline & & & Entire & West & East & Entire & West & East & Entire & West & East \\
\hline Photis sp. 1 & 1 & +68 & $-79 \cdot$ & ns & $-99 \cdots$ & - & 0.16 & - & - & 0.37 & - \\
\hline Jasmineira sp. 1 & 2 & +179 & -71 & ns & ns & 0.30 & 0.14 & 0.06 & 0.69 & 0.25 & 0.10 \\
\hline Prionospio coorilla & 3 & +34 & -60 & $-78^{*}$ & ns & 0.11 & - & 0.22 & 0.86 & - & 0.49 \\
\hline Corbula cf. coxi & 4 & +19 & $-66 \cdots$ & & & - & & & - & & \\
\hline Artacamella dibranchiata & 5 & +6 & $-28 \cdots$ & ns & $-36^{\circ}$ & - & 0.64 & - & - & 0.98 & - \\
\hline Dimorphostylis cottoni & 6 & +1 & +119 & $+141^{\circ}$ & ns & $(0.13)$ & - & $(0.11)$ & $(0.17)$ & - & $(0.13)$ \\
\hline Aricidea sp. 1 & 7 & +4 & -26 & $-41 \cdots$ & ns & 0.22 & - & 0.15 & 0.50 & - & 0.30 \\
\hline Bullowanthura pambula & 8 & -6 & $-0.4 \cdots$ & ns & $-32^{\prime}$ & - & 0.33 & - & - & 0.74 & - \\
\hline Nephtys inornata & 9 & +7 & -3 & ns & $\mathrm{ns}$ & 0.29 & 0.71 & 0.14 & 0.66 & 0.99 & 0.25 \\
\hline Lumbrineris cf. latreilli & 10 & +3 & -18 & ns & $\mathrm{ns}$ & 0.40 & 0.94 & 0.22 & 0.84 & 0.99 & 0.50 \\
\hline Natatolana corpulenta & 14 & +21 & +23 & & & $(0.47)$ & & & $(0.78)$ & & \\
\hline Oedicerotid sp. 1 & 16 & +11 & +71 & $+44^{*}$ & ns & $(0.43)$ & - & 0.12 & $(0.73)$ & - & $(0.21)$ \\
\hline
\end{tabular}


Table 6. Statistical significance of the effect of dredging on abundance $\left[\log _{10} n+1\right.$, except for Jasminiera sp. 1 where $1 /(\mathrm{n}+1)$ transformation was used] of 12 common species when 3,4,5 and 6 post-dredging dates are included in ANOvAs for each species. Probability values are derived from ANOVAs including a sediment covariate, except for Artacamella dibranchiata, Corbula cf. coxi and Natatolana corpulenta, where there was no clear correlation with sediment type (Table 3). Significant changes are shown: $\mathrm{p}<0.10, \cdots \mathrm{p}<0.05, \cdots \mathrm{p}<0.01$. For Lumbrineris cf. latreilli the percentage change during the 5 mo following dredging is shown

\begin{tabular}{|c|c|c|c|c|c|c|}
\hline \multirow[t]{2}{*}{ Species } & \multirow[t]{2}{*}{ Rank } & \multirow[t]{2}{*}{ Plot } & \multicolumn{4}{|c|}{$\begin{array}{l}\text { Number of post-dredging dates included in ANOVA } \\
\text { (time after experimental dredging) }\end{array}$} \\
\hline & & & $3(3.5 \mathrm{mo})$ & $4(5 \mathrm{mo})$ & $5(8 \mathrm{mo})$ & $6(14 \mathrm{mo})$ \\
\hline Photis sp. 1 & 1 & $\begin{array}{l}\text { Entire } \\
\text { West } \\
\text { East }\end{array}$ & $\begin{array}{l}\cdots \\
\cdots\end{array}$ & & & \\
\hline Jasmineira sp. 1 & 2 & $\begin{array}{l}\text { Entire } \\
\text { West } \\
\text { East }\end{array}$ & & & & \\
\hline Prionospio coorilla & 3 & $\begin{array}{l}\text { Entire } \\
\text { West } \\
\text { East }\end{array}$ & $\cdots$ & $\cdot$ & $\cdot \cdot$ & $\because$ \\
\hline Corbula cf. coxi & 4 & Entire & $\cdots$ & $\cdots$ & $\cdots$ & \\
\hline Artacamella dibranchiata & 5 & $\begin{array}{l}\text { Entire } \\
\text { West }\end{array}$ & $\cdots$ & $\cdots$ & $\cdots$ & \\
\hline & 6 & $\begin{array}{l}\text { East } \\
\text { Entire }\end{array}$ & $\because$ & 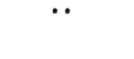 & $\cdots$ & \\
\hline Dhimorphostyis collonis & 0 & $\begin{array}{l}\text { West } \\
\text { East }\end{array}$ & $\cdot$ & $\cdots$ & & \\
\hline Aricidea sp. 1 & 7 & $\begin{array}{l}\text { Entire } \\
\text { West } \\
\text { East }\end{array}$ & $\cdots$ & $\because$ & .. & $\because$ \\
\hline Bullowanthura pambula & 8 & $\begin{array}{l}\text { Entire } \\
\text { West } \\
\text { East }\end{array}$ & $\cdots$ & $\cdot$ & & \\
\hline Nephtys inornata & 9 & $\begin{array}{l}\text { Entire } \\
\text { West } \\
\text { East }\end{array}$ & & & & \\
\hline Lumbrineris cf latreilli & 10 & $\begin{array}{l}\text { Entire } \\
\text { West } \\
\text { East }\end{array}$ & & $\cdot(-25 \%)$ & & \\
\hline Natatolana corpulenta & 14 & Entire & & & & \\
\hline Oedicerotid sp. 1 & 16 & $\begin{array}{l}\text { Entire } \\
\text { West } \\
\text { East }\end{array}$ & · & $\dot{\cdot}$ & $\dot{\cdot}$ & $\dot{\bullet}$ \\
\hline
\end{tabular}

the size of the impact in relation to the background spatial and temporal variability of that species. The distinct east-west gradient across the plots resulted in the abundance of 9 of the 10 most abundant species correlating significantly with the change in sediment type across the plots (Table 4) All species were more abundant in the sandier sediments on the west of the plots, except for Artacamella dibranchiata which was more abundant on the east of the plots and Corbula cf. coxi which showed no gradient across the plots. Consequently, except for $C$. cf. coxi, separate ANOVAs were calculated comparing changes in abundance following dredging between the 2 eastern halves and between the 2 western halves. This approach reduced variability caused by low abundances in only one half, but caused some loss in statistical power as the number of grab samples used in each ANOVA cell decreased from 15 for the entire plots to 7 for half plots.

For all abundant species, except Corbula of. coxi and Artacamella dibranchiata, significance tests of the impact of dredging (Tables 4 \& 5) were based on ANOVAs which included a sediment covariate. A sediment covariate was not included in the ANOVA model used to test the significance of changes to the abundance of $A$. dibranchiata because its abundance did not clearly correlate with sediment type in either the eastern or western halves of the plots (Table 4). The east-west gradient in its abundance appeared to be correlated with another factor (e.g. depth) which was itself correlated with sediment type.

For 12 common species, including the 10 most abundant, heterogeneity of variance was examined using 
Cochran's test and removed by $\log _{10}(n+1)$ for 9 of these species. A $1 / n+1$ transformation effectively removed significant heterogeneity of variance from Jasminiera sp. 1 while no transformations could remove the heterogeneous variances from Photis sp. 1 and Bullowanthura pambula. Consequently the significance of changes to the abundance of Photis sp. 1 and B. pambula need to be interpreted cautiously. The heterogeneous variance for Photis sp. 1 was due to high variances on the control plot immediately following recruitment (Fig. 8) and may be due to patchier recruitment/survival an the more topographically variable control plot. In contrast, high variances with B. pambula occurred on the dredge plot during the first 2 post-dredging samplings (Fig. 8). This increase in variance probably resulted from a temporary redistribution of this species following dredging, when a high proportion of the population may have become concentrated in small undredged regions. The very small but 'significant' change across the entire plots for $B$. pambula (Tables $4 \& 5$ ) results from the high variances on the dredge plot which cause a minimal change in the arithmetic mean on the dredge plot but a decrease in the mean of $\log$ transformed data used in the ANOVA and plotted in Fig 8.

In the 3.5 mo following dredging, 6 of the 10 most abundant species showed a significant decrease in relative abundance of 28 to $79 \%$ on at least the eastern or western halves of the study plots, and 1 species showed a significant increase of $141 \%$ (Table 5). Across the entire plots, 4 species decreased in relative abundance (Photis sp. 1, Jasminiera sp. 1, Prionospio coorilla, and Corbula cf. coxil between 60 and $79 \%$, although only 2 of these changes were significant. These relatively large decreases may result from undersampling of the plots in the pre-dredging period, as measured densities of these species were between 19 and $179 \%$ higher on the control plot than on the dredge plot in the pre-impact period (Table 5). Consequently, if the pre-dredging abundances of these species were actually similar on the control and dredge plots (which seems likely as the plots were wellmatched ecologically), the estimated change following dredging would have been exaggerated by 19 to $179 \%$, and the actual changes in abundance of these species would have been $-11 \%,-26 \%$, and $-37 \%$ for Photis sp. 1, P. coorilla and C. cf. coxi respectively and the abundance of Jasmineira sp. 1 would have increased rather than decreased.

The duration of detectable impacts varied between species. No significant changes in abundance were found with Jasmineira sp. 1 or Nephtys inornata over any time period (Table 6) The low power of statistical tests (Table 5) to detect changes in the abundance of Jasmineira sp. 1, an uncommon species during the first
7 mo of the study (Fig. 8), indicates that the impact of dredging on this species is uncertain. In contrast, the high power of statistical tests (Table 5) to detect changes in the abundance of $N$. inornata indicates that this species decreased in abundance by less than $30 \%$ following dredging (Fig 8). The similarly high power of statistical tests to detect changes in the abundance of Lumbrineris of. latreilli (Table 5) suggests that decreases in the abundance of this species were also less than $30 \%$. Inclusion of 4 post-dredging dates in the ANOVA for $L$. cf. latreilli resulted in a significant decrease of $25 \%$ in the 5 mo following dredging (Table 6 ). Of the 7 species (Table 5) whose abundance changed significantly over the first $3.5 \mathrm{mo}$, Bullowanthura pambula and Photis sp. 1 were affected for 3.5 mo (Table 6, Fig. 8), Dimorphostylis cottoni for 5 mo, Corbula cf. coxi and Artacamella dibranchiata for 8 mo, and Prionospio coorilla and Aricidea sp. 1 for 14 mo (Table 6). As noted above, changes to the abundance of $B$. pambula appear to result from their redistribution rather than a decrease in their abundance; changes do not persist beyond $3.5 \mathrm{mo}$ and indeed the high variances associated with dredging appear to last only $3 \mathrm{wk}$ (Fig. 8). The decreases in populations of Photis sp. 1, C. cf. coxi and A. dibranchiata lasted 1 sampling date beyond the period of recruitment of juveniles. Following recruitment of each of these species, relatively high mortalities on the control plot resulted in convergence of abundances on both plots (Table 6 , Fig. 8). The shorter duration of impact with Photis sp. 1 $(3.5 \mathrm{mo})$ compared to $C$. cf. coxi and A. dibranchiata $(8 \mathrm{mo})$ probably reflected the shorter interval between the dredging impact and the annual recruitment for Photis sp. 1 The abundance of $D$. cottoni increased for 5 mo, after which its abundance on the dredge plot decreased again (Table 6, Fig. 8). The extended persistence of the dredging-related decrease in the abundance of Aricidea sp. 1 on the western side of the dredge plot was probably due to the minimal recruitment of this species in the 14 mo following dredging. In contrast the impact on $P$. coorilla appeared persistent despite significant recruitment on both plots; this may be the result of inadequate sampling in the pre-dredging period. For both Aricidea sp. 1 and P. coorilla, densities on the dredge and control plots were indistinguishable after 14 mo (Fig. 8), but in the pre-dredging period densities were higher on the dredge plot.

\section{Changes in abundance of species groupings}

Taxonomic groups share many morphological and other features that may influence their susceptiblity or resistance to dredging impacts. The abundance of annelids, crustaceans, molluscs and nemerteans de- 
Table 7. Pre-dredging abundance and percentage change in abundance in the 3.5 mo tollowing dredging of species groupings based on (A) taxonomic affinity, (B) feeding types, (C) probable depth of occurrence in sediment, (D) rarity. Significant changes are shown: $p<0.10, \cdots p<0.05, \cdots p<0.01$ Power to detect changes of $30 \%$ and $50 \%$ is shown where changes were nonsignificant. Only those groupings with a pre-impact density $>1.0 \mathrm{~m}^{-2}$ are shown. Suspension-feeding bivalve Theora cf. lubrica (Sp. rank 17) and the scavenging ostracod Empoulsenia sp. 1 (Sp. rank 27) have not been included in the analyses as both had exceedingly contagious distributions

\begin{tabular}{|c|c|c|c|c|c|}
\hline \multirow[t]{2}{*}{ Phylum } & \multirow[t]{2}{*}{ Class } & \multirow{2}{*}{$\begin{array}{c}\text { Pre-dredging } \\
\text { density } \\
\left(\text { No. } 0.10 \mathrm{~m}^{-2}\right)\end{array}$} & \multirow{2}{*}{$\begin{array}{c}\% \text { Change } \\
\text { following dredging }\end{array}$} & \multicolumn{2}{|c|}{ Power, $\alpha=0.10$} \\
\hline & & & & $\begin{array}{c}30 \% \text { decrease } \\
\text { or (increase) }\end{array}$ & $\begin{array}{l}50 \% \text { decrease } \\
\text { or (increase) }\end{array}$ \\
\hline \multicolumn{6}{|c|}{ (A) Taxonomic affinity } \\
\hline \multirow[t]{2}{*}{ Annelida } & & 110.4 & -23 . & & \\
\hline & Polychaete & 110.4 & -23 & & \\
\hline \multirow{7}{*}{ Crustacea } & & 108.6 & $-35(-6)^{1.2}$ & 0.21 & 0.58 \\
\hline & Amphipoda & 73.8 & $-62 \cdots(-7)^{1}$ & & \\
\hline & Brachyura & 2.2 & -31 & 0.20 & 0.56 \\
\hline & Cumacea & 10.3 & $+108(-24)^{2}$ & $\{0.09\}$ & $(0.19)$ \\
\hline & Isopoda & 13.8 & 0 & 0.75 & 0.99 \\
\hline & Mysidacea & 4.4 & +78 & $(0.16)$ & $(0.45)$ \\
\hline & Tanaidacea & 2.6 & -20 & 0.32 & 0.80 \\
\hline \multirow[t]{3}{*}{ Echinodermata } & & 5.3 & +4 & 0.24 & 0.68 \\
\hline & Holothuroidea & 2.5 & -16 & 0.15 & 0.40 \\
\hline & Ophiuriodea & 2.0 & +19 & 0.37 & 0.86 \\
\hline \multirow[t]{3}{*}{ Mollusca } & & 31.0 & $-50 \cdots(-17 \cdot \cdots)^{3}$ & & \\
\hline & Bivalvia & 28.3 & $-53 \cdot(-13)^{3}$ & & \\
\hline & Gastropoda & 2.7 & -22 & & \\
\hline Nemertea & & 2.4 & $-68 \cdot$ & & \\
\hline \multicolumn{6}{|l|}{ (B) Feeding types } \\
\hline Deposit feeder & & 183.5 & $-39 \cdots(-17)^{1}$ & & \\
\hline Predator & & 28.5 & -12 & 0.38 & 0.88 \\
\hline Scavenger & & 5.5 & -21 & 0.57 & 0.98 \\
\hline Suspension-feeder & & 46.8 & $+26(-15)^{2}$ & 0.15 & 0.40 \\
\hline \multicolumn{6}{|c|}{ (C) Probable depth of occurrence } \\
\hline Surface layer & & 76.2 & $-50^{\circ}(+81)^{1}(+29)^{1,2}$ & & \\
\hline Near surface layer & & 32.8 & +11 & 0.44 & 0.93 \\
\hline Below surface & & 65.7 & -26 & 0.36 & 0.85 \\
\hline Well below surface & & 61.9 & -24 & 0.34 & 0.83 \\
\hline \multicolumn{6}{|l|}{ (D) Rarity } \\
\hline Sp. $1-10$ & & 184.5 & $-30 \cdots(-5)^{1}$ & & \\
\hline Sp. $11-20$ & & 33.6 & -6 & 0.27 & 0.72 \\
\hline Sp. $21-30$ & & 21.3 & -22 & 0.66 & 0.99 \\
\hline Sp. $31-50$ & & 16.2 & -23 & 0.99 & 0.99 \\
\hline Sp. $50-247$ & & 16.1 & $-28 \cdots$ & & \\
\hline
\end{tabular}

creased significantly following dredging while there was no significant decrease in the abundance of echinoderms (Table 7A). This difference largely reflects the paucity of echinoderms and the low power of analyses with this phyla (Table $7 \mathrm{~A}$ ). Where phyla could be subdivided into classes it was clear that the component classes were often affected differently by dredging (Table 7A). Similarly where abundant species (e.g. Photis sp. 1, Dimorphostylis cottoni, Corbula cf. coxi) could be identified within a class, these species were often affected differently from the remainder of their class. Thus there was little evidence for a consistent level of impact within a taxonomic group at the level of phylum or class. However, the abundance of nemerteans was decreased $68 \%$ by dredging (Table $7 \mathrm{~A}$ ) and the fragility of this group may make them unusually susceptible to dredging.

Deposit-feeding animals were the best represented trophic group at St. Leonards and accounted for $43 \%$ of the total species. Other groups were less well represented: suspension feeders $(22 \%)$, predators $(19 \%)$, scavengers $(14 \%)$ and grazers $(2 \%)$. Deposit feeders appeared to be more susceptible than predators and scavengers, and suspension feeders became more abundant after dredging (Table $7 \mathrm{~B}$ ). But these patterns were strongly influenced by Photis sp. 1, the most 
abundant deposit-feeding species, and Dimorphostylis cottoni, the most abundant suspension-feeding species (Table 7B). If these 2 species were excluded, then feeding type had no clear influence on the susceptibility of species to dredging impacts (Table 7B).

It seemed likely that species that occurred nearest the sediment surface would be the most susceptible to dredging Unexpectedly, however, except for the amphipod Photis sp. 1, which builds its tube on the sediment surface and whose abundance was reduced by dredging (Table 5), most species that occurred on or near the sediment surface appeared to increase in abundance compared to those which occurred deeper in the sediments (Table $7 \mathrm{C}$ )

Changes to the abundance of species grouped on the basis of their rank abundance indicated that 4 of the 5 species groups decreased in abundance by 20 to $30 \%$, and 2 of these decreases (Sp. 1-10, and Sp. 51-247) were statistically significant (Table $7 \mathrm{D}$ ). The relatively small decrease of $6 \%$ observed with the Sp. 11-21 grouping compared to other species groupings (Table 7D) resulted largely from an increase in abundance of Natatolana corpulenta and a significant $(\mathrm{p}=$ 0.07 ) increase in the abundance of Oedicerotid sp. 1 (Tables $4 \& 5$ ). The increase in abundance of Oedicerotid sp. 1 remained significant $(0.01<\mathrm{p}<0.04)$ for the 14 mo of the study. The abundance of $N$. corpulenta on the dredge plot decreased immediately following the dredging, then increased and remained consistently higher on the dredge plot for $8 \mathrm{mo}$. Thus there was no evidence that rare species were more or less likely to be impacted by dredging than were abundant species.

\section{DISCUSSION}

The design of dredges and the appearance of their tracks indicate that dredges have a grader-like impact on the sea floor. Scallop dredging markedly changed the topography of the experimental dredge plot by flattening callianassid mounds and filling adjacent pits and depressions. Bioturbation caused by Callianassa is a major ecological disturbance in many soft sediment communities (Branch \& Pringle 1987, Griffis \& Suchanek 1991) and is known to reduce the abundance of a range of species including bivalves (Peterson 1977, Murphy 1985), tube-dwelling spionids and amphipods (Posey 1986) and meiofauna (Branch \& Pringle 1987). However, while dredging removed callianassid mounds, it did not significantly reduce the density of callianassids themselves, and it seems unlikely to have reduced bioturbation significantly. Mounds were rebuilt immediately following dredging, although they took 6 to 11 mo to attain their former size. Thus it appears that changes to bioturbation caused by dredging are minimal and similar to those noted following a cyclone which removed Callianassa mounds but did not kill the Callianassa themselves (Riddle 1988).

Sediment cores taken within the study plots at St. Leonards indicated that the majority of organisms $(68 \%)$ were concentrated in the top $5 \mathrm{~cm}$ of sediment, and $91 \%$ in the top $10 \mathrm{~cm}$ of sediment, although some burrowing species (e.g Callianassa) extend well below this depth. The range of species collected in nets placed behind dredges confirmed that much of the infauna was dislodged from the sediment and passed through the dredge cage mesh. When dredging commenced 2 species that occurred in the surface layer Photis sp. 1 and Dimorphostylis cottoni were thrown up in the sediment plume, but as dredging continued deeper sediments were disturbed and more burrowing species, especially polychaetes, were dislodged. The medium-term impact of dredging on 2 surface-dwelling species differed markedly, the abundance of the tube-dwelling amphipod Photis sp. 1 decreased while the cumacean $D$. cottoni increased in abundance following dredging. Unexpectedly, species abundant in net samples, and hence probably over-represented in the surface layer, increased rather than decreased in abundance (Table $7 \mathrm{C}$ ) in the 3.5 mo following dredging. Most of these species were mobile crustaceans ( $D$ cottoni, Paradexamine lanacoura, Oedicerotid sp. 1, Byblis mildura, and Natatolana corpulenta), and their mobility may enable them to migrate opportunistically into disturbed areas with fewer competitors. Alternatively, their mobility may make them less susceptible to dredge-related sedimentation (Brenchley 1981) or more susceptible to being netted. There were few other consistent patterns of susceptibility to dredging between groups of species. Except for nemerteans, which are probably an unusually fragile group, there was no evidence that dredging impacted species from the same phylum or class in a consistent manner. Similarly, susceptibility to dredging was not correlated with feeding type or rarity.

The near absence of general patterns in susceptibility of species groups to dredging is not surprising when the range of possible mechanisms causing mortality or increased migration into a disturbed area are considered. General patterns will probably not emerge until we have a better understanding of the causes of fishing-induced mortality. A number of species, especially burrowing polychaetes and fragile groups such as nemerteans (Table 7A), were probably cut and killed by the passing dredge. Others may have been affected by high turbidity, high rates of sedimentation, or were buried when depressions were filled. Turbidity immediately behind dredges was 2 to 3 orders of magnitude greater than occurs during storms (Black \& Parry 
1994). Laboratory experiments indicate that mortality occurs when invertebrates are exposed to sediment concentrations of 2 to $20 \mathrm{~g} \mathrm{l}^{-1}$ over $21 \mathrm{~d}$ (e.g. McFarland \& Peddicord 1980 cited in Engler et al. 1991). These high concentrations are similar to those that occur immediately behind scallop dredges but such levels last for only a few minutes (Black \& Parry 1994). High rates of sedimentation and burial may also cause some mortality. Species differ greatly in their tolerance of burial (e.g. Maurer et al. 1982), but suspension feeding bivalves, such as Corbula cf. coxi, are generally unable to escape burial of more than $5 \mathrm{~cm}$ (Kranz 1974) and also appear sensitive to high rates of sedimentation (e.g. Howell \& Shelton 1970).

Two species, the cumacean Dimorphostylis cottoni and the amphipod Oedicerotid sp. 1, increased in abundance significantly following dredging. The cirolanid isopod Natatolana corpulenta showed a sharp decrease in abundance immediately following dredging and then its abundance increased and was consistently higher on the dredge plot for $8 \mathrm{mo}$. Two of these species are known to swim actively at night, and Oedicerotid sp. 1 has a large median eye, suggesting that it may also be active nocturnally. The significant reduction in the abundance of many species by dredging may have increased the amount of food available on the plot and attracted some of the more mobile and opportunistic species. For example, $N$. corpulenta may have been attracted to the dredge plot by a greater accessibility of invertebrate prey following dredging. Baited traps deployed in the region at night caught large numbers of $N$. corpulenta, Empoulsenia sp. 1 and smaller numbers of Lysiannasid sp. 1 (Parry pers. ob.). While cirolanids and lysianassids are both well-known scavengers of large carcasses they may have other roles. For example, Oliver \& Slattery (1985) found lysianassids were important predators of invertebrates injured and dislodged from sediments by feeding grey whales, and suggested that small invertebrates may be the most important source of food for lysianassids in other environments.

That the maximum impact does not occur immediately after dredging (Figs. 4 \& 5A) suggests that indirect ecological changes may also follow dredging. Organisms uncovered by dredging may become more vulnerable to predation by invertebrate predators and demersal fish. The increase in the abundance of the scavenger/predator Natatolana corpulenta following dredging was noted earlier and may contribute to a higher mortality of its prey. Changes to the abundance of demersal fish and their diets were monitored during this study and will be described elsewhere (Parry \& Currie unpubl.).

The magnitude and duration of dredging impacts varied between species. In the 3.5 mo following dredg- ing, 6 of the 10 most abundant species showed a significant decrease in abundance of 28 to $79 \%$ on at least one half of the study plots, and 1 species showed a significant increase of $141 \%$ (Table 5) in the 3.5 mo following dredging. But most species decreased in abundance by 20 to $30 \%$ (Tables $5,6 \& 7 \mathrm{D}$ ). Of the 7 species which changed significantly following dredging, differences persisted for 3 wk (Bullowanthura pambula), 3.5 mo (Photis sp. 1), 5 mo (Dimorphostylis cottoni), 8 mo (Corbula cf. coxi and Artacamella dibranchiata) and 14 mo (Prionospio coorilla and Aricidea sp. 1) postdredging. However, the apparent persistent differences with $P$. coorilla and Aricidea sp. 1 may be due to undersampling in the pre-impact period, as the densities of these species were indistinguishable on the control and dredge plots after 14 mo (Fig. 8)

Our most sensitive measure of change following dredging was the $\mathrm{B}-\mathrm{C}$ dissimilarity between the dredge and the control plots (Fig. 4C). For 14 mo following dredging, the dissimilarity between plots remained higher than during the pre-dredging period for all data transformations (Fig. 4C). But the more persistent differences with double square root and presence/absence transformed data suggests that these differences were due mostly to fewer rare species being shared between plots following dredging. There were 11 species found on the dredge plot before dredging that were not found again after dredging, although 5 of these were found on the control plot after dredging. Some of these 11 uncommon species may be very susceptible to dredging, but it appears more likely that dredging reduced densities of most rare species by 20 to $30 \%$ (Table $7 \mathrm{D}$ ) so that each rare species was less likely to be sampled. The particular species not found again on the dredge plot following dredging were probably those that experienced a year of low recruitment and did not recruit to either plot in 1991/92. Thus a similar number of missing species may have been found had the experiment been conducted in another year but the missing species would probably have been different. Most of the 11 species ( 3 bivalves, 2 burrowing polychaetes, 2 burrowing crustaceans, 3 gastropods and 1 squid) found only on the dredge plot before it was dredged are sedentary and so were unable to re-establish on the dredge plot except by larval recruitment.

This study documented the size and duration of scallop dredging impacts on a soft sediment community. Reductions in density caused by dredging were usually small compared to annual changes in population density. The significance of changes to community structure following dredging can also be assessed by comparison with temporal changes in community structure using MDS. Seasonal and particularly interannual changes (see also Poore \& Rainer 1979) were greater than those caused by dredging (Fig. 5). However fur- 
ther studies are required to establish that the results of this study are representative of scallop grounds throughout Port Phillip Bay (Currie \& Parry unpubl.) and to determine whether changes to the benthos cause other ecological consequences, particularly to demersal fish populations (Parry \& Currie unpubl.).

This study is the first to have undertaken a controlled experiment to assess the impact of commercial fishing at a spatial scale similar to that of commercial activities. The appropriate temporal scale for such an experimental study is more difficult to determine. While 14 mo was long enough for the dredged plot to recover almost completely, the difference between the 'recovered' community and the 'never-dredged' community that occurred on this site $30 \mathrm{yr}$ earlier remains uncertain. The long-term effects of dredging may differ from the short- to medium-term changes described here. In particular, after 3 decades of dredging, species that were very vulnerable to dredging may now be too rare in Port Phillip Bay to be adequately sampled. In practice the only species that seem likely to be have been that vulnerable to dredging are long-lived and slowly recruiting epifaunal species such as sponges and ascidians. Ascidians Pyura stolonifera and Herdmania momus remain common at St. Leonards but sponges are not. However, considering the low levels of dredging at St. Leonards over recent years it seems more likely that these slowly recruiting taxa were never common at St. Leonards, unless they are unexpectedly sensitive to dredging. The sector in which the study plots were located was virtually undredged for $3 \mathrm{yr}$ preceding the experimental dredging and in the preceding 8 yr only 9 to $24 \%$ of the sector was dredged annually (Table 1B). But in the absence of quantitative data on completely unimpacted sites, long-term effects can be determined with certainty only with a longterm study in which changes to regions from which the impact is removed are monitored for many years (Gislason 1994). Such recovery studies need proper controls (i.e. sites in which the impact is continued) but their required duration is difficult to predict. A reasonable duration would appear to be the longevity of the longest-lived component species, but frequently this is also unknown.

Acknowledgements. The field program and the laboratory identifications were efficiently coordinated by Ross Haughton and Anold Jahnecke respectively. Special thanks are due to Rhonda Flint, Anna Bos, Matt Hoskins and Mike Forsyth who contributed in the field and the laboratory and to VFRI operations staff especially John Barry, Dave Byer (skipper) and Bob Metcalf (engineer) of RV 'Sarda'. Thanks also to the following staff directly involved in laboratory analysis: Melinda Miller, Steve Frlan, Bruce Waters and Di Crookes and the many (23) staff members at VFRI directly involved in the dredging experiment. The support of the Victorian scallop industry is gratefully acknowledged. We thank specially Melita Proebstl and Gordon Milliken, who coordinated the trials, and the skippers and crews of the following vessels that took part in the experimental dredging: 'AB Hunter', 'AB Venture', 'Conquest', 'Grace', 'Jennann', 'Marie Lizette', 'Nephelle', 'Nimrod', 'Pegasus', 'Saint', 'Sandgroper', 'Tingara' and 'Trinity'. Statistical support was provided by Anne Gason and Nik Dow. Mick Keogh (University of Melbourne) provided valued advice on experimental design. Gary Poore, Robin Wilson and Sue Boyd (Museum of Victoria) checked identifications of all specimens in our reference collection

\section{LITERATURE CITED}

Andrew NL, Pepperell JG (1992) The by-catch of shrimp trawl fisheries. Oceanogr Mar Biol A Rev 30:527-565

Arntz WE, Weber W (1970) Cyprina islandica L. (Mollusca, Bivalvia) als Nahrung von Dorsch und Kliesche in der Kieler Bucht. Ber Dt Wiss Kommn Meeresforsch 21S: 193-209

Belbin L (1.990) PATN technical reference manual. CSIRO Division of Wildlife and Ecology, Canberra

Bergman MJN, Hup M (1992) Direct effects of beamtrawling on macrofauna in a sandy sediment in the southern North Sea. ICES J Mar Sci 49:5-11

Black KP. Parry GD (1994) Sediment transport rates and sediment disturbance due to scallop dredging in Port Phillip Bay. Mem Queensl Mus 36:327-341

Bradstock M, Gordon DP (1983) Coral-like bryzoan growths in Tasman Bay, and their protection to conserve commercial fish stocks. NZ J Mar Freshwater Res 17:159-163

Branch GM, Pringle A (1987) The impact of the sand prawn Calliannassa kraussi Stebbing on the impact on sediment turnover and on bacteria, meiofauna, and benthic microflora. J Exp Mar Biol Ecol 107:219-235

Bray JR, Curtis JT (1957) An ordination of the upland forest communities of southern Wisconsin. Ecol Monogr 27: $325-349$

Brenchley GA (1981) Disturbance and community structure: an experimental study of bioturbation in marine soft-bottom environments. J Mar Res 39:767-790

Britton JC, Morton B (1994) Marine carrion and scavengers. Oceanogr Mar Biol A Rev 32:369-434

Brusca RC, Brusca GJ (1990) Invertebrates. Sinauer Associates, Sunderland, MA

Butcher T, Matthews J, Glaister J, Hamer G (1981) Study suggests scallop dredges causing few problems in Jervis Bay. Aust. Fish 40 (9):9-12

Caddy JF (1973) Underwater observations on tracks of dredges and trawls and some effects of dredging on a scallop ground. J Fish Res Bd Can 30:173-180

Clarke KR (1993) Non-parametric multivariate analyses of changes in community structure. Aust J Ecol 18:117-143

Clarke KR, Green RH (1988) Statistical design and analysis for a 'biological effects' study. Mar Ecol Prog Ser 46:213-226

Cohen J (1988) Statistical power analysis for the behavioural sciences, 2nd edn. L Erlbaum Associates, Hillsdale, NJ, p $1-56$ ?

Currie DR, Parry GD (1994) The impact of scallop dredging on a soft sediment community using multvariate techniques. Mem Queensl Mus 36:316-326

de Groot (1984) The impact of bottom trawling on benthic fauna of the North Sea. Ocean Manage 9:177-190

Eleftheriou A, Robertson MR (1992) The effects of experimental scallop dredging on the fauna and physical environment of a shallow sandy community. Neth J Sea Res 30: $289-299$ 
Engler R, Saunders L, Wright T (1991) Environmental effects of aquatic disposal of dredged material. Environ Prof 13: $317-325$

Faith DP, Humphrey CL, Dostine PL (1991) Statistical power and $\mathrm{BACI}$ designs in biological monitoring: comparative evaluation of measures of community dissimilarity based on benthic macro invertebrate communities in Rockhole Mine Creek, Northern Terntory, Australia. Aust J Mar Freshwat Res 42:589-602

Faith DP, Minchin PR, Belbin L (1987) Compositional dissimilarity as a robust measure of ecological distance. Vegetatio 69:57-68

Fauchald K, Jumars PA (1979) The diet of worms: a study of polychaete feeding guilds. Oceanogr Mar Biol A. Rev 17: 193-284

Field JG, Clarke KR, Warwick RM (1982) A practical strategy for analysing multispecies distribution patterns. Mar Ecol Prog Ser 8:37-52

Gamito S, Raffaelli D (1992) The sensitivity of several ordination methods to sample replication in benthic surveys J Exp Mar Biol Ecol 164:221-232

Gislason H (1994) Ecosystem effects of fishing activities in the North Sea. Mar Pollut Bull 29:520-527

Griffis RB, Suchanek TH (1991) A model of burrow architecture and trophic modes in thalassinidean shrimp (Decapoda: Thalassinidea). Mar Ecol Prog Ser 79:171-183

Gwyther D, McShane PE (1988) Growth rate and natural mortality of the scallop Pecten alba Tate in Port Phillip Bay, Australia, and evidence for changes in growth rate after a 20-year period. Fish Res 6:347-361

HaII SJ (1994) Physical disturbance and marine benthic communities: life in unconsolidated sediments. Oceanogr Mar Biol A Rev 32:179-239

Howell BR, Shelton RGJ (1970) The effect of china clay waste on the bottom fauna of St Austell and Mevagissey Bays. J Mar Biol Assoc UK 50:593-607

Hughes WD (1.973) Operational tests of Victorian scallop boats. Aust Fish 33(5):14-16

Hurlbert SH (1987) Pseudoreplication and the design of ecological field experiments. Ecol Monogr 54:187-211

Hutchings $P$ (1990) Review of the effects of trawling on macrobenthic epifaunal communities. Aust $J$ Mar Freshwat Res 41:111-120

Jamieson GS, Campbell A (1985) Sea scallop fishing impact on American lobsters in the Gulf of St. Lawrence. Fish Bull US 83:575-586

Jones JB (1992) Environmental impact of trawling on the seabed: a review. NZ J Mar Freshwater Res 26:59-67

Kranz PM (1974) The anastrophic burial of bivalves and its paleological significance. J Geol 82:237-265

Krost P, Bernhard M. Werner F, Hukriede W (1990) Otter trawl tracks in Kiel Bay (Western Baltic) mapped by side scan sonar. Meeresforsch 32:344-353

Maurer D, Keck RT, Tinsman JC, Leathem WA (1982) Vertical migration and mortality of benthos in dredged material: Part III. Polychaeta. Mar Environ Res 6:49-68

McFarland VA, Peddicord RK (1978) Lethality of a suspended clay to diverse selection of marine and estuarine macrofauna. Arch Environ Contam 9:733-741

McShane P (1981) The effect of scallop dredging on the macrobenthos of a muddy environment in Port Phillip Bay, Marine Science Laboratories, Queenscliff Tech Rep 4:1-16

Messieh SN, Rowell TW, Peer DL, Cranford PJ (1991) The effects of trawling, dredging and ocean dumping on the eastern Canadian continental shelf seabed. Cont

This article was presented by C. H. Peterson (Senior Editorial Advisor), Morehead City, North Carolina, USA
Shelf Res 11:1237-1263

Murphy RC (1985) Factors affecting the distribution of the introduced bivalve, Mercenaria mercenaria, in a California lagoon - the importance of bioturbation. J Mar Res 43:673-692

Oliver JS, Slattery PN (1985) Destruction and opportunity on the sea floor: effects of gray whale feeding. Ecology 66: $1965-1975$

Parry GD, Currie DR (1992) Interim report on the effects of scallop dredging on Port Phillip Bay. Marine Science Laboratories, Queenscliff, Internal Rep 193:1-67

Peterman RM (1990) Statistical power analysis can improve fisheries research and management. Can J Fish Aquat Sci $47: 2-15$

Peterson $\mathrm{CH}$ (1977) Competitive organisation of the soft-bottom macrobenthic communities of Southern California lagoons. Mar Biol 43:343-359

Peterson CH (1993) Improvement of environmental impact analysis by application of principles derived from manipulative ecology: lessons from coastal marine case histories. Aust J Ecol 18:21-52

Peterson CH, Summerson HC, Fegley SR (1987) Ecological consequences of mechanical harvesting of clams. Fish Bull US 85:281-298

Poore GCB, Rainer S (1974) Distribution and abundance of soft-bottom molluses in Port Phillip Bay, Victoria, Australia. Aust J Mar Freshwat Res 25:371-411

Poore GCB, Rainer S (1979) A three-year study of benthos of muddy environments in Port Phillip Bay, Victoria. Estuar Coast Mar Sci 9:477-497

Posey $\mathrm{MH}(1986)$ Changes in a benthic community associated with dense beds of burrowing deposit feeder, Calliannassa callforniensis. Mar Ecol Prog Ser 31:15-22

Riddle MJ (1988) Cyclone and bioturbation effects on sediments from coral reef lagoons. Estuar Coast Shelf Sci 27: $687-695$

Sainsbury KJ (1988) The ecological basis of multispecies fisheries, and management of a demersal fishery in tropical Australia. In: Gulland JA (1988) Fish population dynamics, 2nd edn. John Wiley, London, p 349-382

Scarrat DJ (1972) Investigations into the effects on lobsters of raking Insh Moss, 1970-1971 Fish Res Bd Can Tech Rep No. 329

Scarrat DJ (1975) Observations on Iobsters and scallops near Pictou N.S. Fish Mar Serv Tech Rep No. 532

Stewart-Oaten A. Murdoch WM. Parker KR (1986) Environmental impact assessment: 'pseudoreplication' in time? Ecology 67:929-940

Thiel H, Schriever G (1990) Deep-sea mining, environmentaI impact and the DISCOL project. Ambio 19:245-250

Underwood AJ (1991) Beyond BACI: experimental designs for detecting human environmental impacts on temporal variations in natural populations. Aust J Mar Freshwat Res 42: 569-587

Warwick RM (1993) Environmental impact studies on marine communities: pragmatical considerations. Aust J Ecol 18: $63-80$

Wassenberg TJ, Hill BJ (1990) Partitioning of material discarded from prawn trawlers in Moreton Bay. Aust J Mar Freshwat Res 41:27-36

Wilson RS, Cohen BF, Poore GCB (1993) The role of suspension-feeding and deposit-feeding benthic macroinvertebrates in nutrient cycling in Port Phillip Bay. CSIRO Port Phillip Bay Environmental Study Technical Report No. 10: 1-41. CSIRO, Melbourne 